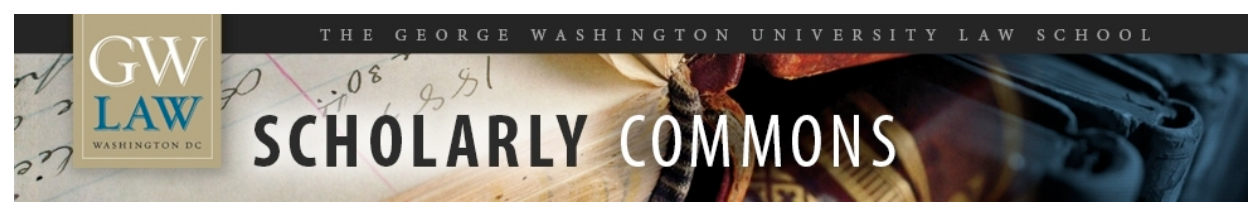

\title{
Military Lawyers on the Battlefield: An Empirical Account of International Law Compliance
}

\author{
Laura T. Dickinson \\ George Washington University Law School, Idickinson@law.gwu.edu
}

Follow this and additional works at: https://scholarship.law.gwu.edu/faculty_publications

Part of the Law Commons

\section{Recommended Citation}

Laura Dickinson, Military Lawyers on the Battlefield: An Empirical Account of International Law Compliance, 104 Am. J. Int'I L. 1 (2007).

This Article is brought to you for free and open access by the Faculty Scholarship at Scholarly Commons. It has been accepted for inclusion in GW Law Faculty Publications \& Other Works by an authorized administrator of Scholarly Commons. For more information, please contact spagel@law.gwu.edu. 


\title{
DRAFT-DO NOT CITE OR QUOTE REFER TO FINAL PUBLISHED VERSION: 104 AM. J. INT'L L. 1 (2010).
}

\author{
MILITARY LAWYERS ON THE BATTLEFIELD: \\ AN EMPIRICAL ACCOUNT OF INTERNATIONAL LAW COMPLIANCE \\ By Laura A. Dickinson *
}

International law scholarship remains locked in a raging debate about the extent to which states do or do not comply with international legal norms. ${ }^{1}$ For years, this debate lacked empirical data altogether. ${ }^{2}$ International law advocates tended to assume that most nations obey most laws most of the time ${ }^{3}$ and proceeded to measure state activity against international norms through conventional legal analysis. ${ }^{4}$ In contrast, international relations realists and rational

\footnotetext{
* Foundation Professor of Law, Sandra Day O'Connor College of Law, Arizona State University. Earlier versions of this paper were presented at a conference held at New York University School of Law, faculty colloquiums at Vanderbilt University School of Law and Duke School of Law, and the Annual Meeting of the Law \& Society Association in Montreal. Many thanks to participants at all of those venues for helpful comments. Additional thanks to Richard Abel, Paul Schiff Berman, Robert W. Gordon, Laurence Helfer, Deena Hurwitz, Harold Hongju Koh, Mike Newton, and Austin Sarat. Most important, thanks are owed for the generous assistance of the Judge Advocate General's Legal Center and School, and to the many attorneys who shared their experiences and insights from the battlefield, and without whose cooperation the empirical data on which this article is based could not have been obtained.

${ }^{1}$ Over a decade ago, Harold Hongju Koh wrote that compliance "remains among the most perplexing questions in international relations" and noted that the question is "fundamental from both a theoretical and practical perspective. It challenges scholars of international law and international relations alike. It vexes all subfields in international affairs, from international security to political economy; from international business transactions to international trade; from European Union law to international organizations." Harold Hongju Koh, Why Do Nations Obey International Law? 106 YALE L.J. 2599, 2599-600 (1997). If anything, debates about compliance have intensified since then. For example, after the publication of Jack L. Goldsmith \& Eric Posner's The Limits of International Law in 2005, which used a rational choice approach in an effort to show that international law has no independent force, no fewer than seventeen review essays were written in response.

${ }^{2}$ See Benedict Kingsbury, The Concept of Compliance as a Function of Competing Conceptions of International Law, 19 MiCH. J. INT'L L. 345, 346 (1998) (“'T] he first empirical task is to determine whether, as is often asserted by international lawyers, most States and other subjects of international law conform to most legal rules most of the time. We have impressions which may rise to the level of 'anecdata,' but in many areas we simply do not have systematic studies to show whether or not most States conform to most international law rules most of the time...." (citation omitted)).

${ }^{3}$ See, e.g., Louis Henkin, How NATions Behave 47 (2d ed. 1979) (“[A]lmost all nations observe almost all principles of international law and almost all of their obligations almost all of the time.").

${ }^{4}$ See Abram Chayes \& Antonia Handler Chayes, The New Sovereignty: Compliance with INTERNATIONAL REGULATORY AGREEMENTS 3 (1995) (“[F]oreign policy practitioners operate on the assumption of a general propensity of states to comply with international obligations.”).
} 


\section{DRAFT-DO NOT CITE OR QUOTE REFER TO FINAL PUBLISHED VERSION: 104 AM. J. INT'L L. 1 (2010).}

choice theorists have argued that international law is simply an epiphenomenon of other state interests with little independent power at all. ${ }^{5}$ Meanwhile, constructivist and transnational legal process approaches have posited that international law seeps into state behavior through psychological and sociological mechanisms of norm internalization and strategic action. ${ }^{6}$ But even these studies tend to remain on a theoretical level, without on-the-ground data about which factors might influence compliance in actual day-to-day settings.

In recent years, international law scholarship has taken a more empirical turn. But this turn has been largely quantitative, relying on relatively blunt numerical measures that lack contextual richness or detailed analysis of the myriad possible causal factors that might explain compliance. ${ }^{7}$ What is missing, even after all these years of debate, is a sustained commitment to qualitative analysis of the actual mechanisms by which compliance occurs. ${ }^{8}$

Such qualitative studies are absolutely essential because they provide the nuance and contextual richness that might allow us to see how subtle factors influence these mechanisms of international law compliance. After all, even when we speak of domestic law, few would dispute that compliance occurs not so much because of fears of enforcement but because of combined

\footnotetext{
${ }^{5}$ See, e.g., Michael Byers, Custom, POWER AND THE POWER OF RUles: InTERNATIONAL RELATiONS AND CUSTOMARY INTERNATIONAL LAW 8 (1999) ("International relations scholars have traditionally . . . regarded international law as something of an epiphenomenon, with rules of international law being dependent on power, subject to short-term alteration by power-applying States, and therefore of little relevance to how States actually behave.”).

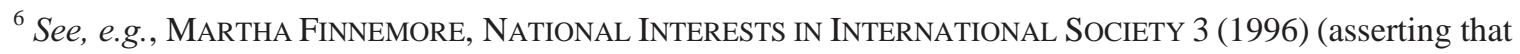
states' interests "are shaped by internationally shared norms and values that structure and give meaning to international political life"); Harold Hongju Koh, Transnational Legal Process, 75 NEB. L. REV. 181, 204 (1996) ("As transnational actors interact, they create patterns of behavior and generate norms of external conduct which they in turn internalize.").

${ }^{7}$ See, e.g., Julian Ku \& Jide Nzelibe, Do International Criminal Tribunals Deter or Exacerbate Humanitarian Atrocities? 84 WASH. U. L. ReV. 777 (2006); Oona A. Hathaway, Do Human Rights Treaties Make a Difference? 111 YALE L.J. 1935 (2002).

${ }^{8}$ See, e.g., LAURA A. Dickinson, EMPIRICAL APPROACHES to InTERnATIONAL LAW (2006). One recent notable exception is Michael P. Scharf, International Law in Crisis: A Qualitative Empirical Contribution to the Compliance Debate, 31 CARDOZo L. REv. 45 (2009). In this article Scharf interviews the ten living former legal advisers of the U.S. Department of State to discuss the influence of international law on the formulation of foreign policy during times of crisis. Thus, Scharf's approach, like mine here, seeks on-the-ground empirical data to create a more nuanced understanding of how international law actually operates in shaping decisions and affecting policy.
} 


\section{DRAFT-DO NOT CITE OR QUOTE \\ REFER TO FINAL PUBLISHED VERSION: 104 AM. J. INT'L L. 1 (2010).}

psychological, sociological, and institutional factors that make obeying the law habitual,

legitimate, socially acceptable, convenient, normal, and so on. It is therefore surprising that

scholars have spent so little time trying to tease out these factors as they debate the compliance question in the international arena.

One potential area for such qualitative analysis is organizational theory. In the domestic context, scholars have used organizational theory in an attempt to isolate structural features of institutions that might make them more or less likely to foster a rules-abiding culture. ${ }^{9}$ Similarly, we might fruitfully apply the insights of organizational theory to the study of international law compliance.

This article uses the framework of organizational theory to guide a qualitative study of international law compliance in what is perhaps the most fraught arena possible: the wartime battlefield. Through a series of interviews with U.S. military lawyers in the Judge Advocate General's (JAG) Corps, I describe and analyze the mechanisms by which these lawyersembedded with troops in combat and consulting daily with commanders- have internalized and seek to operationalize the core values inscribed in international law: respect for human rights and the imposition of limits on the use of force. To be sure, the lawyers are not always successful, and it would be simplistic to assume that their accounts prove that the U.S. military always obeys international law. But their stories support the idea that the presence of lawyers on the battlefield can-at least sometimes_-produce military decisions that are more likely to comply with

\footnotetext{
${ }^{9}$ See, e.g., The New Institutionalism in Organizational Analysis (Walter W. Powell \& Paul J. DiMaggio eds., 1991) [hereinafter NEW InSTITUTIONALISM]; ORGANIZATIONAL ENVIRONMENTS: RITUAL AND RATIONALITY (John W. Meyer \& W. Richard Scott eds., updated ed. 1992) [hereinafter ORGANIZATIONAL ENVIRONMENTS]; ORGANIZATION THEORY: From CHESTER BARNARD TO THE PRESENT AND BEYOND (Oliver E. Williamson ed., 1990) [hereinafter ORGANIZATION THEORY]; JAMES G. MARCH, DECISIONS AND ORGANIZATIONS (1988); JAmes G. March \& Herbert A. Simon, Organizations (2d ed. 1958); W. Richard ScOtT, Organizations (2d ed. 1987); Herbert A. Simon, AdMinistrative BEhAVior (2d ed. 1957); SERGE TAYlOR,

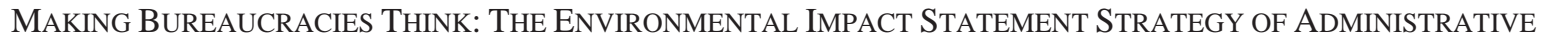
REFORM (1984); Edward L. Rubin, Images of Organizations and Consequences of Regulation, 6 THEORETICAL INQUIRIES L. 347 (2005).
} 


\section{DRAFT-DO NOT CITE OR QUOTE \\ REFER TO FINAL PUBLISHED VERSION: 104 AM. J. INT'L L. 1 (2010).}

international legal norms. This finding mirrors a recent empirical study performed by Michael P. Scharf, in which he recounts, through interviews with ten former legal advisers of the Department of State, multiple instances during the past thirty years when, at the urging of the legal adviser, "U.S. policy-makers decided to forego the use of force or other policy preferences in order to comply with international law." 10 Scharf's study, like mine, suggests that we need to disaggregate abstract notions like "state interest" and look at how decisions are actually reached through the interaction of multiple actors. By doing so, it is much easier to see the constraining role played by international legal norms.

Just as importantly, my study suggests that JAG lawyers are most likely to function effectively and encourage legal compliance if certain organizational features are present. These findings track the organizational theory literature about what makes compliance officers within firms effective. Accordingly, the experience of JAG officers provides a useful case study for testing this broader theoretical literature and suggests links between organizational structure and legal compliance.

Part I of this article briefly introduces some basic insights gleaned from the literature on organizational culture regarding effective compliance agents, and looks at the institutional changes initiated by the U.S. military after the Vietnam War to foster a rule-of-law culture within the services. Part II then presents the results of my study of JAG lawyers operating in Iraq, focusing on the role that organizational structure has played in the effectiveness of these attorneys. What emerges from this analysis is a far more nuanced understanding of how compliance with international legal rules actually operates on the ground. From this perspective, we can begin to see that fostering greater compliance may sometimes be less a matter of writing

\footnotetext{
${ }^{10}$ Scharf, supra note 8 , at 97.
} 


\section{DRAFT-DO NOT CITE OR QUOTE \\ REFER TO FINAL PUBLISHED VERSION: 104 AM. J. INT'L L. 1 (2010).}

new treaty provisions or increasing the activity of international courts and more a matter of subtly influencing organizational structures and cultural norms. Moreover, only by studying organizational culture can we hope to address a world where states alone do not serve as agents of international law compliance but where private corporations with radically varying institutional structures are also often engaged in human rights protection or violation. In this brave new world, international law compliance cannot be described through abstract models, and the sooner we move to a "thick" descriptive approach, ${ }^{11}$ the better.

\section{ORganizational TheORY AND Military CUlture}

Organizational theory has not generally formed part of the study of international law compliance. Yet, as I will attempt to show, this literature, particularly if further developed to focus on institutions applying international law norms, holds tremendous promise and could meaningfully reshape compliance debates. Of particular importance to our analysis here is how compliance agents within an organization—such as lawyers—can most effectively help ensure compliance with central rules and values of the firm, as well as various public norms.

Accordingly, I first turn to the findings of organizational theory on the elements that make for successful compliance agents.

\section{The Importance of Organizational Structure and Institutional Culture}

Organizational theorists have long recognized that group norms and internal organizational structures can further (or hinder) an organization's goals, as well as the goals of

${ }^{11}$ See, e.g., Clifford Geertz, Thick Description: Toward an Interpretive Theory of Culture, in THE INTERPRETATION OF CULTURES: SELECTED ESSAYS 3, 5-6 (1973). 


\section{DRAFT-DO NOT CITE OR QUOTE REFER TO FINAL PUBLISHED VERSION: 104 AM. J. INT'L L. 1 (2010).}

individuals within organizations. ${ }^{12}$ These theorists are a diverse bunch, and they span multiple disciplines, from law ${ }^{13}$ to economics, to sociology, to political science, to anthropology. ${ }^{14}$

Moreover, they study a wide range of organizations, from corporations to private associations, to public bureaucracies. ${ }^{15}$ Thus, it is difficult to generalize about this literature, and a detailed survey is beyond the scope of this article. Instead, I focus on some of the core structural features within organizations that the literature has identified as instrumental in establishing a culture of compliance with external norms, such as legal rules.

As Edward Rubin has argued, organizational theorists can perhaps be divided into four camps: those who view organizations as a nexus of contracts, those who understand organizations as complex decision-making hierarchies, those who see organizations as influenced by broader societal forces or institutions, and those who describe organizations as complex systems or organisms. ${ }^{16}$ For our purposes, these theories are important because, despite their differences, each would predict that the structure of an organization and its institutional culture will have distinct impacts on the efficacy of the organization and the likelihood that actors in it will conform to external norms of behavior.

${ }^{12}$ See sources cited supra note 9.

${ }^{13}$ See, e.g., Rubin, supra note 9. In law, organization theory is most associated with scholars who study the role of professionalization and professional organizations in the activity of lawyers. See, e.g., RICHARD L. ABEL, AMERICAN LAWYERS (2000); ETHICS IN PRACTICE: LAWYERS' ROLES, RESPONSIBILITIES, AND REGULATION (Deborah L. Rhode ed., 2000).

${ }^{14}$ See, for example, for economists' approaches, DoUGLASS C. NORTH, INSTITUTIONS, INSTITUTIONAL Change, And Economic Performance (1990); Oliver E. Williamson, The Mechanisms of Governance (1996). See, for example, for a sociologist's approach, John W. Meyer, Conclusion: Institutionalization and the Rationality of Formal Organizational Structure, in ORGANIZATIONAL ENVIRONMENTS, supra note 9, at 261. See, for example, for a political scientist's approach, Terry M. Moe, The Politics of Structural Choice: Toward a Theory of Public Bureaucracy, in ORGANIZATION THEORY, supra note 9, at 116. See, for example, for an anthropologist's approach, Mary Douglas, Converging on Autonomy: Anthropology and Institutional Economics, in id. at 98.

${ }^{15}$ See, for example, on corporations, Oliver Hart, An Economist's Perspective on the Theory of the Firm, in OrganizATION THEORY, supra note 9, at 154; Edward B. Rock \& Michael L. Wachter, Islands of Conscious Power: Law, Norms, and the Self-Governing Corporation, 149 U. PA. L. REV. 1619 (2001). See, for example, on private associations, ABEL, supra note 13. See, for example, on public bureaucracies, Meyer, supra note 14.

${ }^{16}$ Rubin, supra note 9. 


\section{DRAFT-DO NOT CITE OR QUOTE \\ REFER TO FINAL PUBLISHED VERSION: 104 AM. J. INT'L L. 1 (2010).}

The first group, which includes economists such as Harold Demsetz, Michael Jensen, and William Meckling, ${ }^{17}$ views organizations as simply a nexus of contracts or agreements between rational, autonomous actors. In this view organizations are simply the sum of the contracts that constitute them, and little more. Accordingly, this theory suggests that the terms of the contracts themselves would be the most important way to influence employee behavior. As we shall see, the formal contractual role military lawyers fulfill affects the culture of compliance.

Even more significant for purposes of this study is a second group—-"decision theorists" such as Herbert Simon, James March, and Richard Scott, ${ }^{18}$ as well as economists such as Douglass North and Oliver Williamson ${ }^{19}$ — which views the organization more as a decisionmaking hierarchy. According to this approach, the organization amounts to much more than the sum of its parts: its formal governance structure and informal norms of behavior that cannot be captured in a contract count for just as much. Moreover, this group acknowledges that individuals may not always make rational decisions, and identifies many ways that the structure of a group or organization impedes individuals from making such decisions, contributing to "bounded" rationality.

From the perspective of decision theory, systems of "control, management, supervision, [and] administration, in formal organizations" are critical. ${ }^{20}$ Accordingly, leaders within the organization can define and seek to fulfill the organization's purposes by providing incentives and setting penalties for the organization's members. In addition, the location of a decision within the organization's hierarchy will affect its impact on the organization's members.

\footnotetext{
${ }^{17}$ Armen A. Alchian \& Harold Demsetz, Production, Information Costs, and Economic Organization, 62 AM. ECON. REV. 777 (1972); Michael C. Jensen \& William H. Meckling, Theory of the Firm: Managerial Behavior, Agency Costs and Ownership Structure, 3 J. FIN. ECON. 305 (1976).

${ }_{11}^{18}$ MARCH, supra note 9; MARCH \& SIMON, supra note 9; SCOTT, supra note 9; SIMON, supra note 9.

${ }^{19}$ NORTH, supra note 14; WILLIAMSON, supra note 14.

${ }^{20}$ W. Richard Scott, Symbols and Organizations: From Barnard to the Institutionalists, in ORGANIZATION TheORY, supra note 9, at 38, 39 (quoting CHESTER I. BARNARD, THE FunCTIONS OF THE EXECUTIVE 6 (1938)).
} 


\section{DRAFT-DO NOT CITE OR QUOTE \\ REFER TO FINAL PUBLISHED VERSION: 104 AM. J. INT'L L. 1 (2010).}

Employees may respond more readily to senior managers than to isolated corporate counsels;

indeed, Sally Simpson has found that the idea of violating the law might have a positive appeal as an indication of aggressive business practice. ${ }^{21}$ Nevertheless, as Rubin has noted, an internal compliance program that increases the size and authority of corporate counsel "will tend to increase the salience of the criminal law for operational employees" and their "uncertainty about the consequences of their actions may convince them that it is better to follow the instructions of the compliance personnel."22

Other structural factors are also important. For example, Serge Taylor, in a study of environmental regulation, found that the ability of compliance personnel to monitor lower level personnel and then report back to higher level personnel within the firm increased compliance. ${ }^{23}$ And as Rubin explains:

In the absence of a compliance program, an employee who decides to engage in legally risky behavior, like instituting a cheaper production process that creates more waste, may have nagging doubts about the wisdom of doing so, but will suppress some of those doubts in reporting to his superior, who will, in turn, suppress some of the doubts that were expressed to her in reporting to her superior. Compliance staff may short circuit some of these bureaucratic levels by reporting the employee's doubts directly to top management. $^{24}$

\footnotetext{
${ }^{21}$ SALly S. Simpson, CORPORATE CRIME, LAW, AND SOCIAL CONTROL 116-51 (2002).

${ }^{22}$ Rubin, supra note 9, at 373.

${ }^{23}$ TAYLOR, supra note 9.

${ }^{24}$ Rubin, supra note 9, at 374.
} 


\section{DRAFT-DO NOT CITE OR QUOTE \\ REFER TO FINAL PUBLISHED VERSION: 104 AM. J. INT'L L. 1 (2010).}

Accordingly, the existence of a compliance unit, combined with the ability of compliance employees to report misconduct up a chain of command independent of the operational employee management chain, may enhance compliance.

In addition to the formal organizational structures, informal institutional features can help build (or undermine) a culture of compliance. As Scott notes, citing the classic organizational theorist Chester Barnard, "informal organizations are necessary to the operation of formal organizations as a means of communication, of cohesion, and of protecting the integrity of the individual." ${ }^{25}$ Moreover, Scott highlights the need for inducements of a "“personal, nonmaterialistic character,' including 'the opportunities for distinction, prestige, personal power, and the attainment of dominating position ... [and] ideal benefactions [such as] pride of workmanship, sense of adequacy, altruistic service for family or others, loyalty to organization in patriotism, etc., aesthetic and religious feeling.",26 Thus, "shared values and meanings, internalized by participants, [can] constitute a strong system of control—much more powerful than one based exclusively on material rewards or on force." ${ }^{27}$ Anthropologist Mary Douglas likewise has maintained that one cannot make "good organizational theory without a systematic approach to culture." ${ }^{28}$ For example, the common culture generates conceptions of esteem, a powerful idea that in turn motivates the organization's members:

individuals negotiate with one another over what kinds of esteem their organization will provide (a gold watch at the end of a lifetime of service, a place at High Table, a medal,

\footnotetext{
${ }^{25}$ Scott, supra note 20, at 39 (quoting BARNARD, supra note 20, at 123).

${ }^{26} \mathrm{Id}$. (quoting BARNARD at 122).

${ }^{27}$ Id. at 43.

${ }^{28}$ Douglas, supra note 14, at 98.
} 


\section{DRAFT-DO NOT CITE OR QUOTE \\ REFER TO FINAL PUBLISHED VERSION: 104 AM. J. INT'L L. 1 (2010).}

an obituary notice, a memorial plaque) and the sources of disesteem they will not tolerate (South African investments, dirty washroom, no parking, insult from employers).”29

The critical point, here, is that culture matters, that it varies across organizations, and that "[w] hat the individual is going to want is not entirely his own idea, but consists largely of a set of desires that the social environment inspires in him." 30

As we shall see, the U.S. military has adopted several organizational practices that, according to decision theory, should enhance commitment to the rule of law. With respect to formal structures, judge advocates have a strong role both in training troops and commanders, and in advising commanders in the field, which increase the salience of the law for operational employees. In addition, their ability to mete out criminal and administrative sanctions within the military justice system gives them strong authority. And judge advocates can report abuse through an independent chain of command, as in many of the successful compliance units that theorists have described. Finally, with respect to informal norms and culture, judge advocates construct narratives of commitment to rule-of-law values that contribute to their loyalty to those values.

More recently, a third group of scholars has turned its attention to how organizations respond to external forces, rather than just internal factors. Like the decision theorists who examine the informal norms within organizations, this group is also preoccupied with organizational culture. Yet economists and sociologists who define themselves as "institutionalists" take special interest in the ways the broader environment shapes that internal

\footnotetext{
${ }^{29} I d$. at 102 .

${ }^{30} \mathrm{Id}$.
} 


\section{DRAFT-DO NOT CITE OR QUOTE \\ REFER TO FINAL PUBLISHED VERSION: 104 AM. J. INT'L L. 1 (2010).}

culture. ${ }^{31}$ As a consequence, they might see an organization as adopting a set of values or practices not merely because of their promotion internally, but also because of outside influence.

Thus, scholars of corporations have considered whether elements of national culture have influenced individual and group behavior within particular firms. ${ }^{32}$ In the realm of education within the United States, the sociologist John Meyer has examined whether norms within professional associations might influence their members' practices more than the organization in which they worked. ${ }^{33}$ For example, states (at least prior to the No Child Left Behind Act) tended to deem schools successful on the basis of their teachers' fulfillment of certain professional requirements rather than by evaluating the quality of education in particular classrooms. ${ }^{34}$ Meyer and others also note the existence of "global scripts," which result when many institutions in many settings start to speak about their organization in similar terms by virtue of a prevailing influential narrative. ${ }^{35}$ International law scholars Derek Jinks and Ryan Goodman have argued that states similarly follow particular scripts in adopting and implementing treaty obligations. ${ }^{36}$

For our purposes, the significance of this body of scholarship lies in the suggestion that organizational culture can actually be affected by external forces, including laws, norms, values, and aspirational targets. Consequently, articulating (and defining) international law norms, for example, may have a real impact on institutions even absent mechanisms of enforcement. This

\footnotetext{
${ }^{31}$ NEW InSTITUTIONALISM, supra note 9; ORGANIZATIONAL ENVIRONMENTS, supra note 9.

${ }^{32}$ See, e.g., Richard TANner Pascale \& Anthony G. Athos, The Art of JAPANESE MAnAgEMEnT:

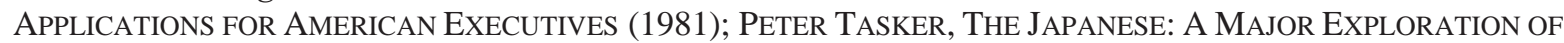
Modern Japan (1988); David G. Litt, Jonathan R. Macey, Geoffrey P. Miller, \& Edward L. Rubin, Politics, Bureaucracies, and Financial Markets: Bank Entry into Commercial Paper Underwriting in the United States and Japan, 139 U. PA. L. REV. 369 (1990).

${ }^{33}$ Meyer, supra note 14; John W. Meyer \& Brian Rowan, Institutionalized Organizations: Formal Structure as Myth and Ceremony, in NEW InSTITUTIONALISM, supra note 9, at 41.

${ }^{34}$ Aaron Benavot, Yun-Kyung Cha, David Kamens, John W. Meyer, \& Suk-Ying Wong, Knowledge for the Masses: World Models and National Curricula, 1920-1986, 56 AM. Soc. REV. 85 (1991).

${ }^{35} I d$. at 145 .

${ }^{36}$ Ryan Goodman \& Derek Jinks, International Law and State Socialization: Conceptual, Empirical, and Normative Challenges, 54 DUKE L.J. 983 (2005).
} 


\section{DRAFT-DO NOT CITE OR QUOTE \\ REFER TO FINAL PUBLISHED VERSION: 104 AM. J. INT'L L. 1 (2010).}

literature also suggests that training regimens can have lasting effects on institutional culture by changing the normative space within the institution.

Finally, a fourth group of scholars_-drawing on the work of Talcott Parsons, Niklas Luhmann, and others-has also focused on the impact of external forces on organizations, but through the lens of systems theory. ${ }^{37}$ These scholars have argued that organizations such as corporations and bureaucracies are themselves systems as well as entities within larger systems. As such, these organizations seek homeostasis when faced with any particular input, although at least some systems theorists argue that external sanctions can have real impact if the external norms are translated and internalized into the terms of the organization. ${ }^{38}$ Accordingly, once again it may be important to have independent compliance agents who can perform this translation function.

Of course, organizations might simply adopt the forms of the external script without imbibing or inculcating the rule. For example, a corporation might adopt compliance or audit requirements simply as a formality without any significant change in internal organizational culture. Moreover, what distinguishes a purely formal shift from one that has a deeper valence can be difficult to distinguish, and the seepage of an institutional change may take years to become truly part of institutional culture. In addition, as scholars in all four of the groups would probably acknowledge, the effectiveness of any of these structures will be constrained by certain

37 Talcott Parsons, The Social System (1951); Niklas LuHManN, Social Systems 6 (John Bednarz Jr. trans., 1995) (1984). See generally WALTER BuCKLEY, SOCIOLOGY AND MODERn SySTEMS THEORY (1967); JAY R. Galbraith, Organization Design (1977); GeOrge J. KliR, An APPROACH to General SySteMS THEORY (1969); Alfred Kuhn, The Logic of Social Systems (1974); TOWARD A Unified THEORY OF HumAN BEHAVIOR (Roy R. Grinker ed., 1956) [hereinafter TOWARD A UNIFIED THEORY]; LUDWIG VON BERTALANFFY, GENERAL SYSTEM THEORY (1968).

${ }^{38}$ Gunther Teubner, Corporate Fiduciary Duties and Their Beneficiaries: A Functional Approach to the Legal Institutionalization of Corporate Responsibility, in CORPORATE GOVERNANCE AND DIRECTOR LIABILITIES: LEGAL, ECONOMIC AND SOCIOLOGICAL ANALySES OF CORPORATE SOCIAL ReSPONSIBILITy, at 149 (Klaus J. Hopt \& Gunther Teubner eds., 1985); Gunther Teubner, Juridification: Concepts, Aspects, Limits, Solutions, in JURIDIfiCATION OF THE SOCIAL SPHERES: A COMPARATIVE ANALYSIS OF THE AREAS OF LABOR, CORPORATE, ANTITRUST AND SOCIAL WELFARE LAW, at 3 (Gunther Teubner ed., 1987). 


\section{DRAFT-DO NOT CITE OR QUOTE \\ REFER TO FINAL PUBLISHED VERSION: 104 AM. J. INT'L L. 1 (2010).}

limits. There may be a deeply pervasive culture of real compliance with particular norms. Or the culture may be only one of paper compliance. The official culture may be committed to particular norms while an unofficial culture is much more complex. Or a culture of compliance may be found at the top of an organization and resistance at the bottom, or the reverse.

What is clear, however, is that organizational culture is one of the most compelling elements in determining which actors will behave in preferred ways and pursue jobs in accordance with preferred norms and values. Furthermore, from the organizational theory literature, we can begin to tease out those structural elements that will help ensure that compliance agents within an organization—-such as lawyers - are actually effective at inculcating values and affecting the behavior of operational employees. These compliance agents are likely to be most effective, it appears, if (1) these agents are integrated with other, operational employees; (2) they have a strong understanding of, and sense of commitment to, the rules and values being enforced; (3) they are operating within an independent hierarchy; and (4) they can confer benefits or impose penalties on employees based on compliance. ${ }^{39}$

Empirical research confirms the importance of these four organizational structures. For example, it turns out that the more company lawyers mingle with other corporate employees, the more likely all employees will be to begin to internalize the legal rules the lawyers seek to enforce. $^{40}$ As a result, the nonlawyer employees become more inclined to take those rules into account when they make decisions. ${ }^{41}$ At the same time, lawyers who interact with other

\footnotetext{
${ }^{39}$ See TAYLOR, supra note 9; Rubin, supra note 9.

${ }^{40}$ See, e.g., SIMPSON, supra note 21.

${ }^{41}$ See Elizabeth Chambliss, MDPs: Toward an Institutional Strategy for Entity Regulation, 4 LEGAL ETHICS 45, 56-64 (2001) (criticizing the American Bar Association's command-and-control approach to entity regulation and calling for more institutional support for in-house compliance specialists); Elizabeth Chambliss \& David B. Wilkins, A New Framework for Law Firm Discipline, 16 GEO. J. LEGAL ETHICs 335 (2003) (proposing that law firms be encouraged to invest in in-house compliance specialists); see also IAN AYRES \& JOHN BRAITHWAITE,
} 


\section{DRAFT-DO NOT CITE OR QUOTE \\ REFER TO FINAL PUBLISHED VERSION: 104 AM. J. INT'L L. 1 (2010).}

employees learn to frame the rules better in terms of broader organizational goals, which in turn

enhances the likelihood that operational employees will follow them. ${ }^{42}$ Research on corporate lawyers also indicates that, if lawyers have a strong sense of obligation to report violationsstemming either from fealty to more senior lawyers within the organization or to a broader professional group and its norms and values - they will be more disposed to confront operational employees who are flouting the rules. ${ }^{43}$ As to the need for an independent chain of command, the data suggest that accountability agents will enforce rules and norms more often if their own promotion, reputation, or advancement is to some degree independent of the operational employees. ${ }^{44}$ Finally, and perhaps not surprisingly, if accountability agents can impose some form of sanction or confer a benefit on employees based on rule compliance, their ability to promote compliance increases. $^{45}$

Accordingly, we must consider the degree to which the organizational structures of the military track the four features described above, and thus contribute to a culture of compliance with public law values. And, if the organizational structure of the uniformed military does contribute to a culture of compliance, then we will need to take those organizational and institutional factors into account when understanding international law compliance more generally, both within the military and in other settings, public and private.

Organizational Structure and Institutional Culture in the U.S. Military

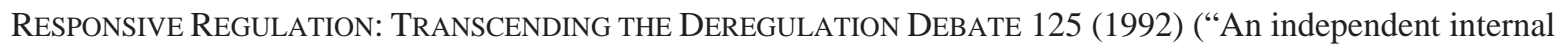
compliance group is essential to the success of an enforced self-regulation scheme.").

${ }^{42}$ See Elizabeth Chambliss \& David B. Wilkins, The Emerging Role of Ethics Advisors, General Counsel, and Other Compliance Specialists at Large Law Firms, 44 ARIZ. L. REV. 559 (2002).

${ }^{43} I d$.

${ }^{44}$ See TAYLOR, supra note 9.

${ }^{45}$ See id. 


\section{DRAFT-DO NOT CITE OR QUOTE \\ REFER TO FINAL PUBLISHED VERSION: 104 AM. J. INT'L L. 1 (2010).}

The U.S. military has a long tradition of at least formal respect for the rule of law and the limits that the law of war places on soldiers. As long ago as the U.S. Civil War, the U.S. Army published the Instructions for the Government of Armies of the United States in the Field of $1863,{ }^{46}$ known as the Lieber Code (because it was prepared by Francis Lieber). The Code set forth rules of conduct for U.S. forces that included limits on the use of force against civilians and humane treatment of detainees. Specifically, the Lieber Code states that " $[\mathrm{m}]$ ilitary necessity does not admit of cruelty - that is, the infliction of suffering for the sake of suffering or for revenge, nor of maiming or wounding except in fight, nor of torture to extort confessions." 47 Indeed, the Lieber Code helped spawn the branch of international humanitarian law that governs the law of hostilities, commonly known as Hague law. ${ }^{48}$ Following the Civil War, the U.S. Armed Forces embraced a culture of respect for law. ${ }^{49}$ The United States also played an active role in furthering the evolution of international humanitarian law from the Civil War to the period after World War II, which culminated in the adoption of the four Geneva Conventions in 1949 and the enactment of the Uniform Code of Military Justice (U.C.M.J.). Throughout this period, the U.S. Armed Forces trained troops in this emerging law of war. Indeed, the U.S. Military Academy began offering courses in the subject as early as $1863 .{ }^{50}$ At the same time, lawyers within the military played a significant role in interpreting and applying these

\footnotetext{
${ }^{46}$ U.S. War Dep't, Instructions for the Government of Armies of the United States in the Field, General Orders No. 100 (Apr. 24, 1863), reprinted in THE LAWS OF ARMED CONFLICTS 3 (Dietrich Schindler \& Jiří Toman eds., $3 \mathrm{~d}$ rev. ed. 1988), available at http://www.civilwarhome.com/liebercode.htm.

${ }^{4} I d$., para. 16.

${ }^{48}$ See Theodor Meron, Francis Lieber's Code and Principles of Humanity, in POLITICS, VALUES, AND FunCtIONS: InTERNATIONAL LAW IN THE 21ST CENTURY 249 (Jonathan I. Charney, Donald K. Anton, \& Mary Ellen O'Connell eds., 1997); see also Thomas G. Barnes, Introduction: Francis Lieber and the Law of War, in LIEBER'S CODE AND THE LAW OF WAR 3 (Richard Shelly Hartigan ed., 1995); Theodor Meron, The Humanization of Humanitarian Law, 94 AJIL 239 (2000).

${ }_{50}$ See generally SAmuel P. Huntington, The Soldier And the StATE (1957).

${ }^{50}$ See Patrick Finnegan, The Study of Law as a Foundation of Leadership and Command: The History of Law Instruction at the United States Military Academy at West Point, 181 MIL. L. REV. 112 (2004).
} 


\section{DRAFT-DO NOT CITE OR QUOTE \\ REFER TO FINAL PUBLISHED VERSION: 104 AM. J. INT'L L. 1 (2010).}

developing laws. The army, for example, has maintained a permanent JAG Corps of military lawyers since $1862 .^{51}$

Nevertheless, the aftermath of the Vietnam War marked a turning point in the uniformed military's relationship to the law of war. The existence of such legal norms obviously had not prevented U.S. troops from committing widespread atrocities at My Lai and elsewhere. After My Lai, a high-level army investigation blamed the military for failure both to train troops adequately in war crimes law and to provide procedures for reporting abuses. ${ }^{52}$ In response, the U.S. military strengthened its internal codes of conduct, updating the U.S. Army Field Manual so that, in addition to specifying prohibited acts, it emphasized that the main objective of wartime detention operations is "implementation of the Geneva Conventions." 53 At the same time, the Department of Defense dramatically stepped up training activities and gave military lawyers a greater role ${ }^{54}$ by initiating a "law of war program," run primarily by the JAG Corps, designed to educate troops from all services in the law of war. ${ }^{55}$ The JAG Corps also gained new responsibilities on the battlefield: judge advocates were placed in the field to develop and review operations plans to ensure compliance with the law of war. ${ }^{56}$ Each commander thus had the benefit of a lawyer's advice in the field, and military lawyers became involved in operational decision making as never before. Such actions helped institutionalize the authority and role of these lawyers in the military bureaucracy. In this way, the military as a whole deepened its

\footnotetext{
${ }^{51} I d$.

521 U.S. DEP' T OF THE ARMY, REPORT OF THE DEPARTMENT OF THE ARMY REVIEW OF THE PRELIMINARY INVESTIGATIONS INTO THE MY LAI INCIDENT (1970), available at http://www.loc.gov/rr/frd/Military_Law/pdf/RDAR-Vol-I.pdf.

${ }^{53}$ James F. Gebhardt, The Road to Abu Ghraib: U.S. Army Detainee Doctrine and Experience, MiL. REV., Jan.-Feb. 2005, at 44, 50 (quoting U.S. Army Field Manual, 1976 ed.).

${ }^{54}$ Frederic L. BORCh, Judge AdVOCATES In COMBAT: ARMY LAWYERS IN MilitARy Operations FROM VIETNAM TO HAITI 30 (2001).

${ }^{55}$ Id. at 37; U.S. Dep't of Defense, DoD Law of War Program, Dir. 5100.77 (Nov. 5, 1974), canceled by id., Dir. 5100.77 (Dec. 9, 1998), available at http://www.au.af.mil/au/awc/awcgate/dod/d510077p.txt (reissuing 1974 directive "to update policy and responsibilities in the Department of Defense," see para. 1.1(a)).

${ }^{56}$ BORCH, supra note 54 , at 31.
} 


\section{DRAFT-DO NOT CITE OR QUOTE \\ REFER TO FINAL PUBLISHED VERSION: 104 AM. J. INT'L L. 1 (2010).}

commitment to the law of war, and, just as significantly, put in place a group of lawyers with a clear mission to enforce adherence to that law.

As a result of these shifts, judge advocates now play a key role in training troops and commanders, before deployment or between deployments, specifically in the rules regarding the limits on the use of force. They also give continuing on-the-ground advice to troops and commanders on a range of legal matters, including the appropriate limits on the use of force. And they are more deeply engaged in investigating misconduct by troops and punishing them, either by imposing administrative penalties or by criminally prosecuting them in military courts.

The JAG training role is extensive. Before deployment, all troops receive training from JAG officers that includes sessions on the legal limits to the use of force. ${ }^{57}$ These sessions may be tailored to the specific types of functions the troops will be performing ${ }^{58}$ and include training in the specific rules of engagement for the particular operation. ${ }^{59}$

In addition, judge advocates themselves receive extensive training. Beyond legal training at an accredited law school, all judge advocates must attend a course at one of the four JAG schools. ${ }^{60}$ Indeed, after the Vietnam War and in response to experiences in Grenada, the military determined that judge advocates should receive training specifically in "the broad ranges of legal issues associated with the conduct of military operations." 61 The recognition that military

57 Interview with JAG Officer No. 14 (Oct. 18, 2007). I interviewed twenty judge advocates, most of whom had served in either Iraq or Afghanistan, or in both, during the previous five years and who had encountered private military contractors. I received permission from the Army JAG School in Virginia, and many of the interviews were conducted at the school in April 2007. Most of the interviewees had been in the JAG Corps for approximately eight years and were at the school for their second round of training. Several additional judge advocates were identified for interview through the so-called snowball method: they were mentioned by one or more of the initial interviewees. A few had served in other conflicts, including the first Persian Gulf war and the conflict in the Balkans in the 1990s.

\footnotetext{
${ }^{58} \mathrm{Id}$.

${ }^{59}$ Interview with JAG Officer No. 16 (Oct. 18, 2007).

${ }^{60}$ Interview with JAG Officer No. 14, supra note 57.

${ }^{61}$ BorCH, supra note 54, at 81.
} 


\section{DRAFT-DO NOT CITE OR QUOTE \\ REFER TO FINAL PUBLISHED VERSION: 104 AM. J. INT'L L. 1 (2010).}

lawyers needed to advise troops and commanders on the ground while deployed resulted in the development of "operational law," which is a "compendium of domestic, foreign, and international law applicable to U.S. forces engaged in combat or operations other than war." ${ }^{2}$ After seven years of service, judge advocates are required to return to the school for another period of extensive training. ${ }^{63}$ The school is staffed by experienced JAG officers who generally serve for terms of two years. ${ }^{64}$ The JAG schools also produce legal handbooks, annually updated by the professors, which judge advocates carry with them into the field. In the case of the Army JAG school, the International and Operational Law Department prepares the Operational Law Handbook, a comprehensive treatise that lays out and analyzes key legal rules. ${ }^{65}$

Since Vietnam, the judge advocates' role prior to deployment has also included helping to draft rules of engagement prior to the operation. ${ }^{66}$ For example, in 1988, judge advocates assisted in drafting such rules in preparation for a possible deployment to Panama. ${ }^{67}$ Similarly, judge advocates participated in drawing up the rules of engagement for Operation Desert Shield, the military operation that enforced a UN embargo on Iraq before the first Persian Gulf war, and for Operation Desert Storm, the first Gulf war itself. ${ }^{6}$

Training continues during deployment, and includes "training exercises," 69 which incorporate specific, realistic scenarios designed to teach the limits on the use of force in specific circumstances the troops are likely to face. Thus, Frederic Borch relates that, during Operation

\footnotetext{
${ }^{62} I d$.

${ }^{63}$ Interview with JAG Officer No. 12 (Oct. 18, 2007).

${ }^{64} I d$.

${ }^{65}$ INTERNATIONAL AND OPERATIONAL LAW DEPARTMENT, JUDGE ADVOCATE GENERAL's LEGAL CENTER \& SCHOOL, U.S. ARMY, OPERATIONAL LAW HANDBOOK (2007), available at http://fas.org/irp/doddir/army/law2007.pdf.

${ }^{66} \mathrm{BORCH}$, supra note 54, at 240.

${ }^{67} \mathrm{Id}$.

${ }^{68} I d$.

${ }^{69} I d$.
} 


\section{DRAFT-DO NOT CITE OR QUOTE \\ REFER TO FINAL PUBLISHED VERSION: 104 AM. J. INT'L L. 1 (2010).}

Uphold Democracy in Haiti, soldiers "were confronted with a vignette in which a speeding vehicle crashed through a traffic check point barrier." A judge advocate "evaluated the soldiers' response and discussed alternative responses available within the limits set by the rules of engagement." ${ }^{, 70}$ Judge advocates continue to hold these types of on-the-ground training sessions in Iraq. ${ }^{71}$ As one senior military lawyer noted, the decisions made as to whether a particular use of force complies with the law of armed conflict or the rules of engagement are "highly situational" and require complex judgment honed by practical experience. ${ }^{72}$

How successful have these reforms been in building an institutional culture within the judge advocates that emphasizes respect for international human rights and humanitarian law? Such a question is probably impossible to answer definitively and almost certainly varies from person to person and context to context. Nevertheless, especially in light of abuses at Abu Ghraib, Guantánamo, and other detention sites, neither the presence of JAG officers in theater nor the various organizational reforms described above have been wholly successful at stopping unlawful behavior.

Yet the period of abuse under the administration of George W. Bush may actually be an illustration not of the failure of the judge advocate system but of its success, at least at the margins. Indeed, we may see the notorious incidents of abuse as precisely what occurs when the JAG culture is deliberately undermined. In the months preceding the abuses at Abu Ghraib, Bush administration officials took a series of steps that weakened longstanding commitments within the military to the norms and values of the law of war, and in particular norms regarding the treatment of detainees. Specifically, administration authorities circulated statements and memorandums suggesting that the law of war might not apply to certain categories of detainees;

\footnotetext{
${ }^{70} I d$.

${ }^{71}$ Interview with JAG Officer No. 20 (Oct. 16, 2007).

${ }^{72}$ W. Hays Parks, Remarks at conference held at the University of Virginia School of Law (Oct. 15, 2007).
} 


\section{DRAFT-DO NOT CITE OR QUOTE \\ REFER TO FINAL PUBLISHED VERSION: 104 AM. J. INT'L L. 1 (2010).}

issued multiple, confusing directives to troops on the ground regarding permissible interrogation techniques; allowed civilian intelligence personnel, special forces, uniformed troops, and private contractors to mingle without clear lines of authority or divisions of responsibility; and greatly expanded the role of private contractors. Together, these practices helped set the stage for the abuses that took place.

Just as importantly, the commitment of many within the military to the values of international law, and the organizational structures that the military had constructed over many decades to maintain those commitments, proved surprisingly difficult to dislodge. For it was, primarily, the civilian political employees who sought to change longstanding military practices. Uniformed military personnel and military lawyers, by contrast, in many cases took the lead in criticizing the administration and sought to tame the effect of administration policies, while reaffirming (and perhaps even reinstitutionalizing) the military's respect for international law. As David Luban has pointed out, “[T]heir primary roles as criminal litigators and military advisors converge to make JAGs staunch and faithful rule of law devotees, possibly to an extent greater than many civilian lawyers.",73

In fact, although senior administration officials seeking to narrow the reach of international law in the fight against terrorism often deliberately excluded military lawyers from the conversation, ${ }^{74}$ those lawyers, both active and retired, worked both in public and behind the scenes to try to thwart or moderate administration policies. For example, during the debate that followed the president's initial order establishing the use of military commissions to try terrorism suspects, military lawyers were notably vocal. A team of administration political appointees from the White House, the Office of Legal Counsel, and Vice President Dick Cheney's office worked

\footnotetext{
${ }^{73}$ David Luban, Lawfare and Legal Ethics in Guantánamo, 60 STAN. L. REV. 1981, 2000 (2008).

${ }^{74}$ Tim Golden, After Terror, a Secret Rewriting of Military Law, N.Y. TIMES, Oct. 24, 2004, §1, at 1.
} 


\section{DRAFT-DO NOT CITE OR QUOTE \\ REFER TO FINAL PUBLISHED VERSION: 104 AM. J. INT'L L. 1 (2010).}

largely in secret to prepare the order, and excluded military lawyers (as well as lawyers from the

State Department) from the process. Immediately after the release of the order, however, military lawyers strongly criticized the plan, specifically the denial of important procedural protections to defendants, including the lack of a right to choose a lawyer or requirement of a unanimous vote for death sentences. ${ }^{75}$ These lawyers also expressed concern that, over time, the lack of protections in the proposed military commissions would undermine perceptions of the fairness of military justice more broadly, even though the U.C.M.J. includes strong protections for the rights of the accused. ${ }^{76}$

Partly in response to such criticisms, the Bush administration developed regulations that softened some of the most disputed provisions and required, for example, unanimity before the death penalty could be imposed, a presumption of innocence, proof beyond a reasonable doubt, and a military appeals process. ${ }^{77}$ Yet, as the commissions began their work, the military lawyers appointed to defend the accused continued to challenge the process, particularly because of the lack of judicial review in civilian courts. ${ }^{78}$ And after the Supreme Court struck down the use of commissions as originally constituted, military lawyers again asserted themselves as vocal opponents of the administration's efforts to resurrect the panels. ${ }^{79}$ Lawyers objected, above all, to the new commissions' rules that would allow the admission of evidence defendants had not

\footnotetext{
${ }^{75}$ William Glaberson, Tribunal v. Court-Martial: Matter of Perception, N.Y. TiMES, Dec. 2, 2001, §1B, at 6 (citing Edward Sherman, former Army lawyer and former dean of Tulane Law School); see also Golden, supra note 74.

${ }^{76}$ Glaberson, supra note 75 (citing John S. Cooke, a retired army judge who was chair of the American Bar Association Section on Armed Forces Law).

${ }^{77}$ Neil A. Lewis, A Nation Challenged: The Military Tribunals; Rules on Tribunal Require Unanimity on Death Penalty, N.Y. TIMES, Dec. 28, 2001, at A1.

${ }^{78}$ Neil A. Lewis, Lawyer Says Detainees Face Unfair System, N.Y. TIMES, Jan. 22, 2004, at A25; Jonathan Mahler, Commander Swift Objects, N.Y. TIMES, June 13, 2004, §6 (Magazine), at 42.

${ }^{79}$ Mark Mazzetti \& Neil A. Lewis, Military Lawyers Caught in Middle on Tribunals, N.Y. TIMES, Sept. 16, 2006, at A1.
} 


\section{DRAFT-DO NOT CITE OR QUOTE \\ REFER TO FINAL PUBLISHED VERSION: 104 AM. J. INT'L L. 1 (2010).}

seen. $^{80}$

Military lawyers also repeatedly criticized the broad policy guidance and field directives regarding interrogation practices. Indeed, military lawyers strenuously resisted the recommendations in the memorandums of the Office of Legal Counsel and a Defense Department working group that largely adopted a very narrow definition of torture and a broad definition of presidential authority. ${ }^{81}$ For example, Brig. Gen. Kevin M. Sandkuhler, a senior marine lawyer, wrote in a memorandum of February 27, 2003, that the harsh interrogation regime could ultimately have adverse repercussions for American service members. ${ }^{82}$ The statement pointedly declares that the Department of Justice "does not represent the services; thus, understandably, concern for service members is not reflected in their opinion." ${ }^{83}$ Likewise, Maj. Gen. Thomas J. Romig, the army's top-ranking uniformed lawyer, wrote in a memo of March 3, 2003, that the approach recommended by the Justice Department "will open us up to criticism that the U.S. is a law unto itself." 84

Criticism of the field directives regarding specific interrogation practices was similarly strong. The deputy judge advocate general of the air force, Maj. Gen. Jack L. Rives, advised that many of the "more extreme interrogation techniques, on their face, amount to violations of domestic criminal law,' as well as military law. ${ }^{85}$ Rives argued that the use of these techniques "puts the interrogators and the chain of command at risk of criminal accusations abroad,' in other countries' domestic courts or international tribunals. ${ }^{86}$ And in September 2003, military

\footnotetext{
${ }^{80} \mathrm{Id}$.

${ }^{81}$ On the memorandums, see, for example, Sean D. Murphy, Contemporary Practice of the United States, 98 AJIL 820-31 (2004).

${ }^{82}$ Neil A. Lewis, Military's Opposition to Harsh Interrogation Is Outlined, N.Y. TIMES, July 28, 2005, at A21.

${ }^{83}$ Id. (quoting Brig. Gen. Kevin M. Sandkuhler, memorandum (Feb. 27, 2003)).

${ }^{84}$ Id. (quoting Maj. Gen. Thomas J. Romig, memorandum (Mar. 3, 2003)).

${ }^{85} \mathrm{Id}$. (quoting Maj. Gen. Jack L. Rives).

${ }^{86} \mathrm{Id}$.
} 


\section{DRAFT-DO NOT CITE OR QUOTE \\ REFER TO FINAL PUBLISHED VERSION: 104 AM. J. INT'L L. 1 (2010).}

lawyers objected to Gen. Ricardo Sanchez's authorization of the controversial interrogation techniques in Iraq discussed previously. The lawyers argued that these techniques were "overly aggressive,', presumably because they would run afoul of the U.C.M.J. and international law. ${ }^{87}$ Finally, military lawyers pushed for significant revisions to the U.S. Army Field Manual on intelligence interrogations. The new manual, released in September 2006, specifies that the Geneva Conventions apply to all detainees and eliminates distinctions between prisoners of war and enemy combatants. ${ }^{88}$ Thus, throughout the period 2002-2006, we see a military legal culture fighting back against efforts by political appointees to weaken or muddy the U.S. commitment to the law of war.

This Bush-era experience does suggest that organizational culture can play a crucial role either in weakening, or giving effect to, international law. To the extent that international law failed to constrain troops on the ground from committing abuses, it was at least in part because Bush administration political appointees took steps that effectively undermined a bureaucratic culture that had institutionalized respect for that law. Yet that culture - a military committed to the law of war and the fair treatment of detainees_also proved to be adhesive. ${ }^{89}$ Organizational practices and values remained resilient, and served as the origin for much of the critique of, and resistance to, these changes.

The foregoing seems to indicate that the existence of a cadre of lawyers within the military structure who retain primary allegiance to human rights norms and the laws of war can

\footnotetext{
${ }^{87}$ V. Adm. Albert T. Church III, REVIEW OF Department of DEFENSE Detention OperATIONS AND DETAINEE INTERROGATION TECHNIQUES [CHURCH REPORT], Executive Summary at 8 (Mar. 11, 2005), available at http://www.dod.gov/pubs/foi/detainees/church_report_1.pdf.

${ }^{88}$ Jeannie Shawl, New US Army Interrogation Manual Mandates Geneva Rules, JURIST, Sept. 6, 2006. Congress, however, subsequently exempted CIA operatives from the requirements of the Field Manual, except when operating under Defense Department control or within a Defense Department facility. See Detainee Treatment Act of 2005, $\$ 1002(\mathrm{a}), 10$ U.S.C. $\$ 801$ note (2006).

${ }^{89}$ For an argument about the role that military culture can play in deterring war crimes, see generally MARK J. OSIEl, Obeying ORders: Atrocity, Military DisciPline, AND THE LAW OF WAR (1999).
} 


\section{DRAFT-DO NOT CITE OR QUOTE \\ REFER TO FINAL PUBLISHED VERSION: 104 AM. J. INT'L L. 1 (2010).}

have a real impact, at least in the main. Further, the most effective organizational structure would be one designed to give these lawyers a deeply contextual role, helping design rules of engagement, providing situational training in theater, and advising commanders on a day-to-day basis. Yet institutional design, when translated into practice, can obviously fall short of its lofty aims. The next part therefore presents empirical data on the way this organizational structure plays out on the ground.

\section{JUDGE ADVOCATES ON THE BATTLEFIELD}

Uniformed military lawyers - the career judge advocates — are essentially the compliance unit within the military. These lawyers work to ensure that commanders and troops obey the rules of engagement, which are the rules that operationalize the law of armed conflict in a given war or occupation. The core public value undergirding this body of law is the principle that the use of force, even in an armed conflict, is limited. Specifically, troops may not target civilians, and the use of force must be proportional to the risk or danger present. Thus, military lawyers are essential to inculcating this public value into military culture.

Interviews with more than twenty uniformed military lawyers who served primarily in Iraq and Afghanistan indicate that the current military structure includes all four elements of a successful compliance unit that were discussed above. Judge advocates mingle with operational employees, the commanders and troops on the battlefield. They help devise the rules of engagement and train troops in those rules, both before they deploy and on the battlefield. At the same time, their ongoing advice to commanders and commanders' staff on the battlefield appears to make the legal rules they seek to enforce more salient throughout the organization. The lawyers report that they frame the rules in a way that describes them as supporting the broader 


\section{DRAFT-DO NOT CITE OR QUOTE \\ REFER TO FINAL PUBLISHED VERSION: 104 AM. J. INT'L L. 1 (2010).}

goals of the organization: military effectiveness. These lawyers also profess a strong sense of commitment to the rules and the values that underlie them. And while the judge advocates face some challenges in establishing credibility, an independent chain of command-which obliges them to report incidents and serves as a basis for supplemental guidance in the field and as a basis for promotion that is separate from that of the operational employees-helps bolster the lawyers' independence and objectivity. Furthermore, uniformed lawyers play a key role in ensuring that commanders impose penalties on rule breakers within the military justice system. These include both administrative punishments such as loss in pay or rank, as well as more severe criminal penalties.

Of course, the accounts of JAG officers are likely to be self-serving and may therefore overstate the effectiveness of military lawyers. And, as noted above, an organizational structure, even if effective, can certainly be undermined through strategic maneuvering. Nevertheless, while having all of the organizational features in place does not necessarily guarantee norm compliance, there is evidence that the military lawyers do exert a very real impact on military operations, at least some of the time. As a result, we need to study the organizational structures that tend to increase norm compliance, even if that compliance remains imperfect. After all, no norm compliance regime is perfect, and an imperfect regime may still be significant, particularly when compared with even more imperfect alternatives.

\section{Integration of Lawyers and Troops on the Battlefield and the Salience of Legal Rules}

As discussed above, since Vietnam the military has vastly expanded the role of judge advocates in the field. Judge advocates now serve alongside commanders on the battlefield, giving advice on a range of issues from troop discipline to fiscal decision making, to vetting 


\section{DRAFT-DO NOT CITE OR QUOTE \\ REFER TO FINAL PUBLISHED VERSION: 104 AM. J. INT'L L. 1 (2010).}

targets, to interpreting rules of engagement. Indeed, during the Iraq war the army has actually expanded the role of the judge advocates. Accordingly, military lawyers who once served primarily at the higher, division level and above, now work with commanders in the field down to the brigade level.

The lawyer's role on the battlefield. Judge advocates based in Iraq and Afghanistan describe assuming a wide variety of roles: they might investigate, prosecute, or defend soldiers in criminal matters or matters of military discipline; they might train troops on emerging issues involving the rules of engagement; and they might provide a range of operational legal advice to commanders on everything from fiscal issues, to troop discipline, to targeting. The precise set of legal questions addressed depends in part, of course, on the level of the assignment. The division level, for example, includes multiple lawyers who are likely to specialize in specific areas of law, all reporting to a division judge advocate who supervises the lawyers and supplies advice to the division commander. At the brigade level, in contrast, usually only one or two lawyers handle all matters that might arise.

The location and type of military assignment—Baghdad or Kirkuk, a detention facility or a city neighborhood - also affect the types of issues these lawyers face. For example, one lawyer, assigned to a brigade in Baghdad, said that his legal role was linked to the overall role of the brigade: "patrolling the battle space, controlling and pacifying it." 90 Accordingly, the lawyers were there "to bring the rule of law" to the area. "[We] owned that land."91 Another, by contrast, advised a commander in charge of a military detention facility. ${ }^{92}$ Yet another served as the senior defense counsel for a region of Iraq. Based in Baghdad, this lawyer observed that "every day I

\footnotetext{
${ }^{90}$ Interview with JAG Officer No. 7 (Oct. 16, 2007).

${ }^{91} I d$.

${ }^{92}$ Interview with JAG Officer No. 1 (Oct. 16, 2007).
} 


\section{DRAFT-DO NOT CITE OR QUOTE \\ REFER TO FINAL PUBLISHED VERSION: 104 AM. J. INT'L L. 1 (2010).}

was flying out, trying cases, interviewing witnesses, talking to [the criminal investigative division]." 93

But regardless of the assignment, the judge advocates were clearly putting themselves right in the heart of the conflict. The danger was particularly acute during one of the most violent periods of the Iraq engagement, the Shiite uprising of 2004-2005. As one judge advocate noted, during this moment in the conflict, "every day was a long day." 94 In the period from March 2004 through February 2005, 947 troops died, an average of 79 each month. ${ }^{95}$

At least in its ideal form, the operational/law relationship is one in which lawyers have the ear of the commander and the commander's staff for a range of operational decisions. As one judge advocate who served in Baghdad described it, "all targets are supposed to be cleared through us." 96 And, as he further noted, "it's a big job because you can't shoot at a lot of stuff in Baghdad." 97 Another judge advocate reported that "[the operational law issues that arose] tended not so much to be targeting issues but, rather, issues related to troops in contact, and selfdefense." 98 As an example, this judge advocate described an incident in which "a Bradley was hit by a ... car bomb":

Everyone survived. They left the weapons and the documents in the back of the car. There were some tough decisions to make .... Some people were looking at taking the weapons and wanted to know whether under the ROE [Rules of

\footnotetext{
${ }^{93}$ Interview with JAG Officer No. 4 (Oct. 16, 2007).

${ }^{94}$ Interview with JAG Officer No. 7, supra note 90.

${ }_{95}$ See iCasualties.org, Operation Iraqi Freedom (2009), available at http://icasualties.org/Iraq/Index.aspx.

${ }^{96}$ Interview with JAG Officer No. 7, supra note 90.

${ }^{97} \mathrm{Id}$.

${ }^{98}$ Interview with JAG Officer No. 8 (Oct. 16, 2007).
} 


\section{DRAFT-DO NOT CITE OR QUOTE \\ REFER TO FINAL PUBLISHED VERSION: 104 AM. J. INT'L L. 1 (2010).}

Engagement] we were allowed to do it. [I determined that it was OK under the

ROE of the time.] I helped the commander with the decision matrix. ${ }^{99}$

This judge advocate further observed that “not all situations are rehearsed; you can't train for everything. That's why it was important that I was on the scene. You involve yourself in the fight." 100

Training troops and revising the rules of engagement. Training is an important part of the operational role. As one judge advocate noted, the pre-deployment training is "extensive." 101 Another observed that "we spend a lot of time training up our kids .... They get [the rules of engagement] beaten into their heads at the start," before they deploy. ${ }^{102}$ "Then, they get more training in Kuwait," just before they enter the theater. ${ }^{103}$ And when they are on the battlefield, they receive yet more training in the appropriate limits on the use of force. Moreover, at each stage, the training goes beyond recitation of the rules and involves detailed discussion (and sometimes role playing) about specific scenarios likely to arise on the battlefield in question. One judge advocate explained that it is also not mere training in the classroom: "We go through scenarios, we practice, and see what happens."104

To be sure, the judge advocates acknowledged that training might not always prevent troops from crossing the line and using excessive force. As one interviewee conceded, "if a

\footnotetext{
${ }^{99}$ Id.

${ }^{100} I d$.

${ }^{101} \mathrm{Id}$.

${ }^{102}$ Interview with JAG Officer No. 7, supra note 90.

${ }^{103} \mathrm{Id}$.

${ }^{104}$ Interview with JAG Officer No. 8, supra note 98.
} 


\section{DRAFT-DO NOT CITE OR QUOTE \\ REFER TO FINAL PUBLISHED VERSION: 104 AM. J. INT'L L. 1 (2010).}

soldier's scared, he's going to shoot." 105 This lawyer reasoned that, as a consequence, "it's

important not to set too many restrictions [and instead] to train them to realistic scenarios."106

The judge advocates also give updated refresher courses to troops in theater, and revise

both the training scenarios and the rules of engagement themselves to reflect the conditions on the ground. One judge advocate emphasized the importance of this "revised training in the field." 107 As another put it, "we re-set the training to build up habits-we give them a refresher in the status quo." 108 And the judge advocates play an active role in revising the training scenarios. According to one of those interviewed:

There were thirty thousand soldiers in Baghdad. Every time there was an incident [in which a soldier used force] we'd do a 15-6 tracker, and report it. That way, we'd pick up real-life scenarios that we'd use for training. We'd update it on a monthly basis. There were probably thirty incidents a day. ${ }^{109}$

This judge advocate noted further that whenever there was a potential issue of excessive force, they would conduct an investigation. Another judge advocate states that "we take a look at the circumstances in which people are getting killed," and think about "how we can stop so we don't need to use deadly force but at the same time ensure that our soldiers are not attacked."110 This judge advocate recounted circumstances in which he thought "we weren't getting it right," so he

\footnotetext{
${ }^{105}$ Interview with JAG Officer No. 7, supra note 90.

${ }^{106} \mathrm{Id}$.

${ }^{107}$ Interview with JAG Officer No. 8, supra note 98.

${ }^{108}$ Interview with JAG Officer No. 2 (Oct. 16, 2007).

${ }^{109}$ Interview with JAG Officer No. 7, supra note 90.

${ }^{110}$ Interview with JAG Officer No. 8, supra note 98.
} 


\section{DRAFT-DO NOT CITE OR QUOTE \\ REFER TO FINAL PUBLISHED VERSION: 104 AM. J. INT'L L. 1 (2010).}

sent a report tracker to division headquarters to alert "people at a higher level that we have a problem."111

Mingling and credibility: part of the team. Uniformed lawyers describe their integration with officers and troops on the battlefield as essential to their ability to inject legal norms and values into the decision-making process. They emphasize that their position on the battlefield gives them the opportunity to interact at the moment that decisions are made. Moreover, they were present when the commander and staff laid out the battle plan.

In that connection, the judge advocates have a strong sense that they should get to know as many on the staff as possible: "[You] need to get out. .. . [You] can't sit in your office all day. You've got to be out shaking hands, getting to know people ... it's a huge task."112 Relatedly, judge advocates stressed the need to vet legal concerns with the commander and the commander's staff at an early stage, before a formal meeting takes place. As one judge advocate put it, "If I raised a serious legal concern for the first time at a meeting with the commander and staff, I'd get my head handed to me."113 This judge indicated that "it's important to try to find legal alternatives [at the planning stage]."114

According to the judge advocates, the integration of lawyers and troops also enhances the lawyers' credibility, because it demonstrates that they are participating in a common mission; although they are lawyers, they are soldiers first and foremost. "When you're a JAG at the brigade level, you have to assume a soldier role, not just a lawyer role. You don't earn trust unless you do the soldier part." 115 This judge advocate recalled that "we used to look at the

\footnotetext{
${ }^{111} I d$.

${ }^{112}$ Interview with JAG Officer No. 6 (Oct. 16, 2007).

${ }^{113}$ Interview with JAG Officer No. 8, supra note 98.

${ }^{114} I d$.

${ }^{115}$ Interview with JAG Officer No. 5 (Oct. 16, 2007).
} 


\section{DRAFT-DO NOT CITE OR QUOTE \\ REFER TO FINAL PUBLISHED VERSION: 104 AM. J. INT'L L. 1 (2010).}

lawyers like the doctors," who played no combat role. But now "the lawyers sit in the room" when combat decisions are made. "When there's a military decision-making process in place, the lawyer should be there. If you are involved, everyone can see the value added. The staff and the commander see you as part of the team rather than a weenie lawyer." ${ }^{116}$ And just as important as developing rapport with the commander is building relationships with staff officers, because "it's a cell of staff officers who work on [each] issue."117 Accordingly, "[you have to] inject yourself . .. so they know you're not there just to [sit behind a desk] but to add value .... [You have to] inject yourself socially so you can be there professionally." 118

Many judge advocates noted that combat experience before becoming a lawyer helped them to build trust with the commanders and their staffs once they assumed the role of lawyer. For example, one judge advocate, a marine, argued that "it's easier in the marines" than in the other services because "every marine, whether serving in the infantry, in supply, or as a lawyer . . . everyone goes to the same officer candidate school and has the same basic training: how to be an [infantry platoon commander]." ${ }^{119}$ There is "a common culture, a common crucible of experience." ${ }^{120}$ As a result, "yes, there is commander skepticism. But less than in the army."121 Another judge advocate emphasized that his background as an armor officer before joining the JAG Corps had helped: "I'm comfortable with a [combat role]. I had a common background I could share." 122

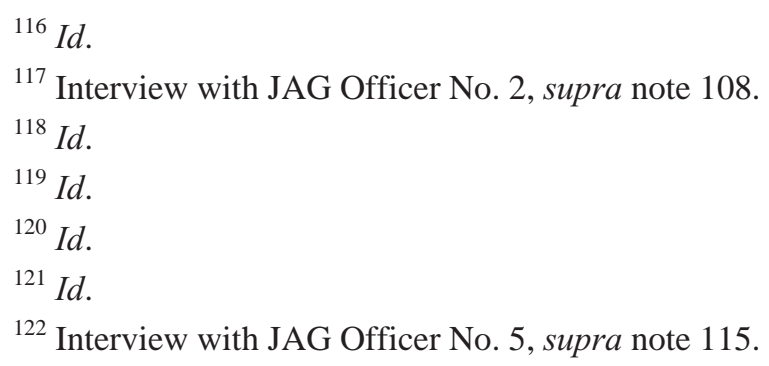




\section{DRAFT-DO NOT CITE OR QUOTE \\ REFER TO FINAL PUBLISHED VERSION: 104 AM. J. INT'L L. 1 (2010).}

Similarly, a judge advocate who had previously trained to become an officer in the armed forces said that because he had attended the Naval Academy and then West Point before he became a lawyer, he had "instant credibility."123 "People remembered me," he said. ${ }^{124}$ He further maintained that credibility by "doing [physical training], combatives, going to the range, and wrestling with the noncoms and staff." 125 "I stayed in shape," he continued. "I showed them that I didn't mind bloodying my nose . . . . It was clear that I was one of them." 126

Several judge advocates specifically stressed the need to go out in the field with troops and be with them in dangerous situations. As one lawyer explained, "If [there was an issue involving] troops in contact, if [there was a] developing situation, my job was to be there ... not in the back of the [tactical operations center] listening to the radio, waiting until something happened." ${ }^{27}$ Consequently, "I would engage [the enemy] if necessary, [and] I worked closely with fire support, field artillery ... . I became tied in ... . Even if you're not needed, you're there." 128

It is precisely this kind of mingling of accountability agents and operational employees that organizational theory credits with increasing the effectiveness of these agents. Thus, instead of being walled off from the rest of the organization, judge advocates speak with commanders and their staffs about the rules of engagement every day in the thick of battle, which increases general awareness of the importance of these rules, and together they engage in discussions about how best to interpret them. As one judge advocate recounts, "my brigade commander was brilliant, and he expected alternative views ... . If an IED [improvised explosive device] went

\footnotetext{
${ }^{123}$ Interview with JAG Officer No. 8, supra note 98.

${ }^{124} I d$.

${ }^{125} \mathrm{Id}$.

${ }^{126} I d$.

${ }^{127} I d$.

${ }^{128} I d$.
} 


\section{DRAFT-DO NOT CITE OR QUOTE \\ REFER TO FINAL PUBLISHED VERSION: 104 AM. J. INT'L L. 1 (2010).}

off, and we were going to respond, he wanted to know, 'Is it a good shoot or a bad shoot?' . . .

[And if] I had concerns, he listened to me." 129 This kind of integral involvement of lawyers in core decisions gives greater depth and meaning to the legal rules.

To be sure, the judge advocates face challenges in building credibility and rapport in the field. As one noted, "Some people see lawyers as difficult .... [So they engage in] tough guy banter, and make lawyer jokes. They see lawyers as making [the military] less effective."130 Another acknowledged that, in the field, commanders and staff really include judge advocates in the decision-making process only "50 percent of the time." 131 In addition, there is the problem of "forum shopping: [a commander or staff officer might] request an opinion from three different JAGs." 132

For these reasons, one judge advocate, a professor at the army's Judge Advocate School, indicated that the school actually teaches "building rapport." 133 Accordingly, the professors emphasize in the classroom that "all law is in an operational environment." 134 Each judge advocate should therefore seek to "build a relationship with everyone in [the commander's] staff. Hopefully, they come to you. Hopefully they do it before they take action. Hopefully you've vetted [their plans]: you can say something like, 'All three causes of action look legal' [but the third is riskier from a legal perspective]." ${ }^{\prime 35}$ Putting such advice into action, one military lawyer described his approach in similar terms:

\footnotetext{
${ }^{129}$ Interview with JAG Officer No. 5, supra note 115.

${ }^{130}$ Interview with JAG Officer No. 2, supra note 108.

${ }^{131}$ Interview with JAG Officer No. 18 (Feb. 12, 2007).

${ }^{132}$ Interview with JAG Officer No. 6, supra note 112.

${ }^{133} I d$.

${ }^{134} \mathrm{Id}$.

${ }^{135} \mathrm{Id}$.
} 


\section{DRAFT-DO NOT CITE OR QUOTE \\ REFER TO FINAL PUBLISHED VERSION: 104 AM. J. INT'L L. 1 (2010).}

If there were three options on the table, and all were legal, I might say something like,

"This option is close to the line, this one is safe, and this one is in the middle. As long as the option is legal, I'm there to ensure you accomplish the mission." 136

As a result, the judge advocates carefully translate their legal advice into operational terms, making it clear to commanders that the lawyers' job is not to say no but, rather, to help their commanders achieve the objectives of the mission. As one judge advocate put it, "You can't be Dr. No." ${ }^{137}$ Even if a particular course of action posed legal problems, "our job was to give an alternative course of action that would accomplish the goal without the legal concerns." 138 Another judge advocate put it this way: "[I] wanted to help my commander get to yes." 139 Similarly, a third reported that his job was "finding a way to yes . . your first response shouldn't be no." ${ }^{140}$ Instead, "you should think, 'How can I help my commander accomplish the objective?",141 If there's a legal problem, "then you say, 'OK, you want to do $x$, but why do you want to do $x$ ? Maybe it's better to try something else.", 142

Many judge advocates also observed that the personal relationship between a judge advocate and a commander is crucial and that the best way to build credibility is to give good advice. According to one judge advocate, "Each commander is very different, so the job is very

\footnotetext{
${ }^{136}$ Interview with JAG Officer No. 8, supra note 98.

${ }^{137} \mathrm{Id}$.

${ }^{138} \mathrm{Id}$.

${ }^{139}$ Interview with JAG Officer No. 2, supra note 108.

${ }^{140}$ Interview with JAG Officer No. 3 (Oct. 16, 2007).

${ }^{141} \mathrm{Id}$.

${ }^{142} \mathrm{Id}$.
} 


\section{DRAFT-DO NOT CITE OR QUOTE \\ REFER TO FINAL PUBLISHED VERSION: 104 AM. J. INT'L L. 1 (2010).}

personality driven. You could be successful with one commander, but not another." ${ }^{143}$ In that vein, another lawyer emphasized that every relationship "has to be built from scratch. You start with little things and build up to bigger things." ${ }^{144}$ Furthermore, when you are "deployed, it can be harder to do" than when you are in the garrison. ${ }^{145}$ In one judge advocate's view, "Your credibility depends on how much the commander respects [your] individual competence."146 Consequently, "[i]t's hard. If you give one bad opinion, [the commander] may be less likely to come to you. You take the risk that [the commander might go] to another unit, or above you to the corps/division level." ${ }^{147}$ In contrast, if the commander "follows your advice," has good results, and gets "credibility," that will build his trust and respect. ${ }^{148}$

A strong sense of commitment to the legal rules and underlying values. The judge advocates expressed a strong sense of commitment to the legal rules applicable in theater and the underlying values they reflect. Indeed, they seemed to see their role as the guardians of ethics within the military, and all those interviewed tended to describe their role in similar terms. Thus, one judge advocate said that uniformed lawyers have an "ethical duty" to protect the applicable rules and laws, including the rule regarding the use of force. ${ }^{149}$ Another related that the "JAGs in the army push to inject ethics" into the conduct of a military conflict. ${ }^{150}$ "[W] [Wen [your] job is to fight and kill, you try to do it with some sense of integrity ... you want the army to be able to say that." ${ }^{151}$ A third judge advocate described his role as standing for "integrity and to be the

\footnotetext{
${ }^{143}$ Interview with JAG Officer No. 6, supra note 112.

${ }^{144}$ Interview with JAG Officer No. 2, supra note 108.

${ }^{145} \mathrm{Id}$.

${ }^{146}$ Interview with JAG Officer No. 6, supra note 112.

${ }^{147} I d$.

${ }^{148}$ Interview with JAG Officer No. 3, supra note 140.

${ }^{149}$ Interview with JAG Officer No. 2, supra note 108.

${ }^{150}$ Interview with JAG Officer No. 5, supra note 115.

${ }^{151} I d$.
} 


\section{DRAFT-DO NOT CITE OR QUOTE \\ REFER TO FINAL PUBLISHED VERSION: 104 AM. J. INT'L L. 1 (2010).}

commander's conscience ... not like an inspector general but rather an internal conscience." ${ }^{152}$

Yet another said, "We're the organization's ethics counsel.",153

This ethical role is viewed as having both an internal and an external component, encouraging integrity within the military as well as advancing the military's mission in the eyes of the broader public in the United States and elsewhere in the world. One judge advocate expressed that idea as follows:

The linchpin that holds us together at the end of the day is that the rule of law has to exist where citizens believe in equal protection, fairness, equity, justice. [We] make sure it exists within the military, and through leverage within our own organization to other countries we're trying to help, from demonstration. ${ }^{154}$

With respect to the internal culture, another judge advocate noted that "sometimes JAGs get jaded .... [They see] all the crap ... that there are criminals, child molesters, and child pornographers in the military" just like everywhere else. ${ }^{155}$ This lawyer stressed the importance of the judge advocate's role in impressing upon the military itself, as well as the broader public, that the services are "not controlled by criminals." 156 For example, when a general testifies in Congress, "we want to be able to say we do everything right ... [and take] the moral high

\footnotetext{
${ }^{152}$ Interview with JAG Officer No. 2, supra note 108.

${ }^{153}$ Interview with JAG Officer No. 8, supra note 98.

${ }^{154}$ Interview with JAG Officer No. 4, supra note 93.

${ }^{155}$ Interview with JAG Officer No. 5, supra note 115.

${ }^{156} \mathrm{Id}$.
} 


\section{DRAFT-DO NOT CITE OR QUOTE \\ REFER TO FINAL PUBLISHED VERSION: 104 AM. J. INT’L L. 1 (2010).}

ground." 157 Another judge advocate added that "we can only fight the global war on terror by holding onto our core values, [and by] establishing the rule of law." 158

Judge advocates also underlined that uniformed lawyers should make every effort to remain independent and objective. One pointed out that "you want to set your commander up for success." "159 To do that, "you [need to give] objective advice on army policies and the law." Moreover, this judge advocate advised, you have to remember that your "client is the U.S. Army," not a particular commander. Accordingly, it is crucial not to let the thick of war cloud one's judgment: "you need to [say the same] thing in the theater as in the garrison." 160

An independent hierarchy. Judge advocates describe another feature that enhances their effectiveness in the field, the ability to seek what they call "top cover" through an independent chain of command within the JAG Corps. This path of alternate authority—separate from the commander to whom the judge advocate is assigned — serves as a backup in cases where a commander may be reluctant to listen to the assigned judge advocate. Thus, a judge advocate working with a brigade commander might seek the advice of a judge advocate at a higher level in the chain of command, such as the staff judge advocate assigned to the division commander (to whom the brigade commander reports). As one judge advocate noted:

[You might seek] top cover if you want higher level support. It's common if your commander doesn't seek your advice, or if you advise your commander that the course of action he wants to take is a violation of law. It's relatively common for a judge advocate

\footnotetext{
${ }^{157} I d$.

${ }^{158}$ Interview with JAG Officer No. 4, supra note 93.

${ }^{159}$ Interview with JAG Officer No. 8, supra note 98.

${ }^{160} \mathrm{Id}$.
} 


\section{DRAFT-DO NOT CITE OR QUOTE \\ REFER TO FINAL PUBLISHED VERSION: 104 AM. J. INT'L L. 1 (2010).}

at the brigade level, for example, to seek advice from the lawyer at the division or corps

level and ask, "Could you look at this and see if I'm right?",161

This judge advocate emphasized, however, that the practice "could be abused if the judge advocate routinely seeks such opinions." 162

Numerous other judge advocates described using the practice of top cover. One of them explained that "we do have a system [within the JAG Corps] . . your commander's commander has a lawyer." 163 This judge advocate found that it is sometimes helpful "to talk to lawyers at higher headquarters." ${ }^{\prime 64}$ The more senior lawyer can provide further ammunition in arguments with the commander or, through the senior lawyer's commander, influence the lower level commander. As one judge advocate recounts, "If I disagreed with my commander, I could go to the division staff judge advocate, who was a friend." ${ }^{165}$ He believed that "talking to the division staff judge advocate" was most useful if "you had a horrible relationship with your commander or you disagreed." "166 He acknowledged that "the staff judge advocate might say that you're wrong," but "if you're right, the staff judge advocate could talk to the brigade commander."167

The judge advocates reported that the practice is relatively common, though it poses some challenges of its own. According to one judge advocate:

${ }^{161}$ Interview with JAG Officer No. 6, supra note 112.

${ }^{162} \mathrm{Id}$.

${ }^{163}$ Interview with JAG Officer No. 12 (Oct. 16, 2007).

${ }^{164} I d$.

${ }^{165}$ Interview with JAG Officer No. 5, supra note 115.

${ }^{166} I d$.

${ }^{167} \mathrm{Id}$. 


\section{DRAFT-DO NOT CITE OR QUOTE \\ REFER TO FINAL PUBLISHED VERSION: 104 AM. J. INT'L L. 1 (2010).}

Top cover happens often. It's not looked down upon. You may need more seasoned advice. For example, if you have time and you're faced with a difficult targeting decision, you may want to run it by a more senior lawyer .... Or if you're having a problem with your commander, you might want to ask a more senior lawyer to speak to your commander and say, "I need you to intervene, and tell him my role.", 168

Another judge advocate related that "I would often send stuff up to the corps level and get a quick turnaround." 169 Furthermore, he said, "I had no problem going to corps if needed," and "they were very good about sending down advice." ${ }^{170}$ Yet some judge advocates warned against seeking such advice on basic questions. ${ }^{171}$ While "you can talk to the lawyer" up the chain without doing so, going up the chain of command works best if "you get permission" from your commander first." 172 But, this judge advocate continued, "if [he says no, [it's a sign that] something is wrong .... Your conscience should say, "Wait, the train is off the track.",173

In addition to using the independent chain of command, some judge advocates report using the "CNN factor" to persuade commanders to follow their advice, meaning that a certain action "would look bad on CNN." 174 The possibility of congressional testimony is also a motivating factor: "When the generals are called to testify in Congress, you want them to be able to say, 'We do everything right.' You want them to be able to take the moral high ground.",175

\footnotetext{
${ }^{168}$ Interview with JAG Officer No. 6, supra note 112.

${ }^{169}$ Interview with JAG Officer No. 7 (Oct. 17, 2007).

${ }^{170} \mathrm{Id}$.

${ }^{171}$ Interview with JAG Officer No. 6, supra note 112.

${ }^{172}$ Interview with JAG Officer No. 2, supra note 108.

${ }^{173} I d$.

${ }^{174}$ Interview with JAG Officer No. 7, supra note 169.

${ }^{175}$ Interview with JAG Officer No. 5, supra note 115.
} 


\section{DRAFT-DO NOT CITE OR QUOTE \\ REFER TO FINAL PUBLISHED VERSION: 104 AM. J. INT'L L. 1 (2010).}

When it comes to incidents involving the use of force, judge advocates described a strong sense of obligation to report them up the chain of command:

What does a JAG do if there are organizational issues at the brigade? You have to go outside the brigade, even if there are career repercussions. Your client is the army, and you have an ethical obligation to the army. There's no attorney-client privilege with the commander . . . it's a very important concept.",176

This judge advocate also observed that "[i]t's important to err on the side of caution and report incidents [up the chain of command]." ${ }^{177}$ Moreover, "you have to have little career ambition .... [Even if it hurts our professional advancement], we have to police ourselves." ${ }^{178}$ Another lawyer recalled that "[a]ny time a soldier fired, we'd report it up through the division" and that in "any incident where the force might be excessive, we investigated." ${ }^{179}$ If, for example, "there was a shooting at a checkpoint, we'd do a [report].",180

The ability to report incidents up an independent chain of command appears to give judge advocates extra leverage in trying to persuade commanders to follow a specific course of conduct. For example, one judge advocate described how his ability to report independently helped him convince a reluctant commander to report an incident of potential abuse. He noted that "you can go through the divisional chain, if you need to. " ${ }^{181}$ "Sometimes you can win an argument [with the commander] if you say you have to report . . you may burn a bridge, but it's

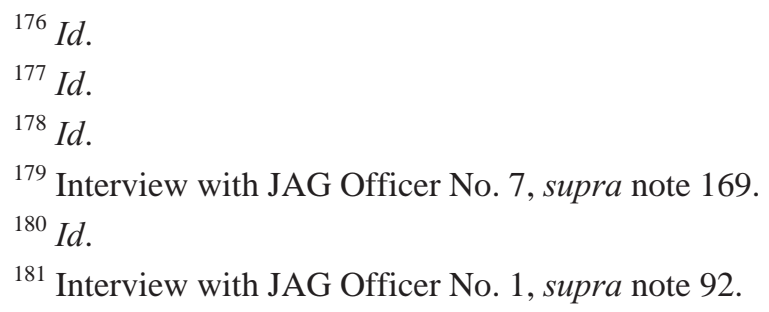




\section{DRAFT-DO NOT CITE OR QUOTE \\ REFER TO FINAL PUBLISHED VERSION: 104 AM. J. INT'L L. 1 (2010).}

necessary." 182 According to this judge advocate, though it was "understandable" that the commander preferred not to record the event, "I told him I had to report it up to the division, and he understood." 183

Significantly, senior uniformed lawyers, not the commander for whom the judge advocate is working, are primarily responsible for performance reviews and promotion decisions regarding individual judge advocates. The judge advocates indicated that the commanders to whom they are assigned do provide performance evaluations, but the more senior supervising judge advocate in the field also contributes an important evaluation. One judge advocate stated, "I worked directly for G3 [my commander], but my rating chain of command was through the SJ [senior judge advocate]." ${ }^{184}$ This structure helps insulate the judge advocates and gives them a greater sense of independence.

Accountability: the imposition of administrative and criminal sanctions. In protecting the public values that are embedded in military rules, judge advocates wield a strong stick: they can investigate soldiers who violate those rules, and, in appropriate cases, recommend that those soldiers be brought before courts in the justice system internal to the military, where they may be tried and punished. In fact, the ability of uniformed military lawyers to refer miscreants to this system is one of the most significant differences between judge advocates and corporate counsel or other organizational accountability agents, who lack the ability to invoke a criminal justice system internal to their organization. Corporations and bureaucracies do not have their own criminal courts. And corporate counsel typically do not have the authority to recommend that employees be penalized within the organization for rule infractions — and in most cases may not

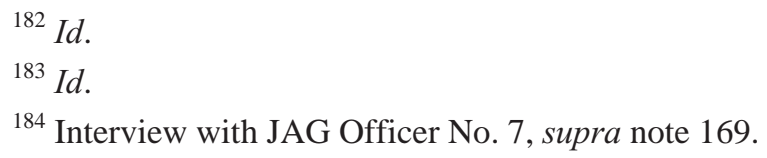




\section{DRAFT-DO NOT CITE OR QUOTE \\ REFER TO FINAL PUBLISHED VERSION: 104 AM. J. INT'L L. 1 (2010).}

even disclose those infractions to civilian criminal authorities. The closest analogy is to

corporations or bureaucracies with an internal dispute resolution mechanism that can impose

noncriminal penalties on employees who break the rules.

The judge advocates' ability to invoke the internal military justice system extends not merely to criminal acts, but also to acts in violation of military rules that, while not ordinarily rising to the level of a crime, would undermine military discipline. ${ }^{185}$ Accordingly, in any given case a judge advocate can recommend that a commander initiate either a general court-martial procedure, which allows for the full range of penalties including jail time, or a more abbreviated Article 15 proceeding, which permits only weaker administrative penalties. ${ }^{186}$ The penalties arising from these proceedings can range from full-fledged criminal punishment to reductions in pay or rank, or dishonorable discharge. ${ }^{187}$ The judge advocates are therefore central enforcers of military discipline.

Enforcement begins at the investigative stage. In cases where troops have allegedly misused force, the judge advocate will work together with the criminal investigative unit. Judge advocates, at least in the army, must report any incident in which a soldier fires a weapon. ${ }^{188}$ The judge advocates reported that they often learned of cases from civilians, who would complain to the battalion in charge of the area when they or family members were injured in an incident involving the military. The judge advocate would then make an assessment based on the quality of the evidence as to whether to proceed: "We would move ahead when the claim sounded

${ }^{185}$ The Uniform Code of Military Justice, 10 U.S.C. $\$ \$ 801-946$ (2006), provides that soldiers may be punished for many such acts. See, e.g., 10 U.S.C. $\$ 889$ (disrespect toward superior commissioned officer); 10 U.S.C. $\S 892$ (failure to obey order or regulation); 10 U.S.C. $\$ 912$ (drunk on duty); 10 U.S.C. $\$ 915$ (malingering); 10 U.S.C. $\S 933$ (conduct unbecoming an officer and a gentleman).

${ }^{186}$ See 10 U.S.C. $\$ 815$ (2006) (U.C.M.J. Art. 15, Commanding Officer’s Non-Judicial Punishment).

${ }^{187}$ See 10 U.S.C. $\$ \$ 856 a, 858$ a (2006).

${ }^{188}$ Interview with JAG Officer No. 7, supra note 169. 


\section{DRAFT-DO NOT CITE OR QUOTE \\ REFER TO FINAL PUBLISHED VERSION: 104 AM. J. INT’L L. 1 (2010).}

legitimate; . . it depends on the source, on the evidence." ${ }^{189}$ If the facts so warranted, judge advocates could initiate a process that would compensate the victims financially.

The judge advocates could also recommend that commanders initiate proceedings against troops who might be implicated in such an incident, or indeed any incident that would constitute a crime under military law or a violation of military discipline. As one judge advocate observed, "if a marine violated the rules, he'd be court-martialed and punished." 190 This judge advocate cited the example of a marine who was implicated in an act of extortion. The judge advocate noted that the marine was sent back to the United States to Camp Lejeune and punished. ${ }^{191} \mathrm{~A}$ troop who flouted military rules — such as those banning drinking and drugs—could also be subject to court-martial. ${ }^{192}$ To be sure, judge advocates can seek to reduce penalties as well. One judge advocate described urging a commander to opt for an Article 15 process to discipline a soldier who had misbehaved, rather than use the general court-martial process and its stiffer penalties. ${ }^{193}$ This judge advocate said that, in an Article 15 proceeding, "you can take rank and pay. It saves face with troops. It takes a fair approach . . . [and] allows them to rehabilitate, which is important, especially if the person is a good soldier." 194

In sum, in the field judge advocates are present at all stages of the law: they seek to shape behavior in advance by advising commanders, staff, and troops. And when violations occur, they can initiate punishment.

\section{Effectiveness of Judge Advocates-Saying No}

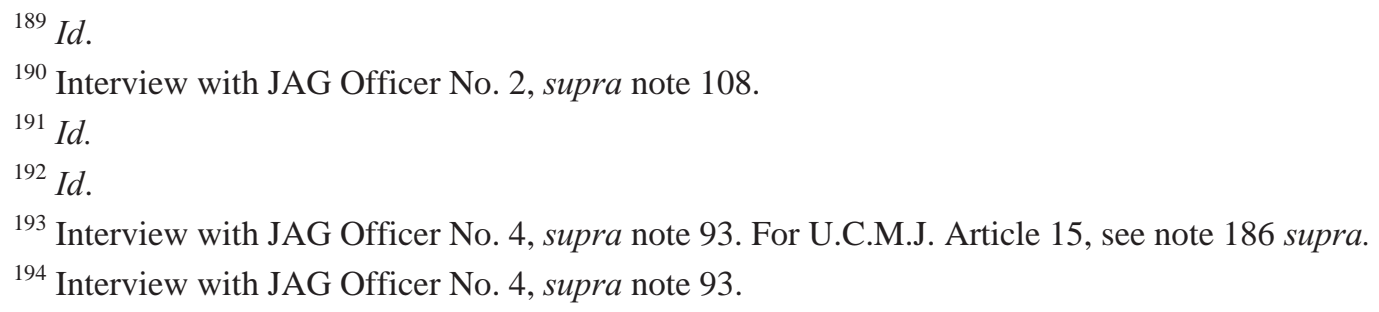




\section{DRAFT-DO NOT CITE OR QUOTE \\ REFER TO FINAL PUBLISHED VERSION: 104 AM. J. INT'L L. 1 (2010).}

Of course, it cannot be said for certain how effective these various organizational features - the mingling of lawyers and troops, an independent chain of command, the ability to impose criminal and administrative penalties — are in actually protecting public law values on the ground. As mentioned above, the perceptions of the judge advocates are bound to be somewhat self-serving. Nevertheless, the interviews do shed some light on this question. For example, one measure of whether judge advocates help protect public values (such as the rules limiting the use of force) is whether they can really guide commanders away—at least on occasion—from behavior that would undermine those values. While judge advocates take care not to describe their role as saying no to commanders, many were able to name cases in which they did persuade commanders not to follow a particular course for legal reasons. The judge advocates interviewed were by no means pollyannas about their role. On the contrary, they were acutely aware that the system breaks down, and that loyalty to a particular commander or unit sometimes trumps the lawyer's commitment to broader public values. Yet they see themselves as having an impact. And despite their natural bias on this question, it does seem clear that, at least some of the time, having a strong, independent lawyer present matters.

As discussed above, uniformed lawyers were reluctant to describe their job as saying no to commanders and, instead, cast themselves as finding alternative means within the law to enable commanders to accomplish military objectives. ${ }^{195}$ In this regard they are actually very much like most business counselors or transactional lawyers.

Judge advocates did, however, describe some instances in which they went further and actively intervened to try to stop commanders from taking a particular action. As one judge advocate reported, “[On occasion] I said, 'Sir, this is a bad idea, you should do this differently.' I

195 See text at notes 139-42 supra. 


\section{DRAFT-DO NOT CITE OR QUOTE \\ REFER TO FINAL PUBLISHED VERSION: 104 AM. J. INT'L L. 1 (2010).}

saw my role as helping my brigade commander keep out of jail and helping to keep troops out of jail." ${ }^{196}$ When steering a commander away from a specific course with legal problems, one lawyer noted, "With fiscal issues, it's easy. You just can't buy certain things with unit money. But even then, there may be some other way to accomplish the goal ...."197 Especially in the wake of Abu Ghraib, he added, "Interrogation is also easy ... no commanders want to [go to jail]." 198 Another judge advocate observed that in most circumstances in which a legal issue arises, "it's a plan that's just not well thought out, so . . you try to work around the problem." As an example, a different lawyer told of advising his commander to take a more restricted response after an IED went off at the base. ${ }^{199}$ Likewise, when a commander wanted to respond in a certain way to a hand grenade attack, the judge advocate "did not say 'no,' [but] I said [the response] was not legal."200

Admittedly, the judge advocates mentioned difficulties that might arise in steering commanders away from legally questionable actions. Several brought up the case of Haditha, an incident from 2005, in which marines allegedly fired without provocation on Iraqi civilians as revenge after their compatriot was killed by a roadside bomb. ${ }^{201}$ Many of the lawyers remarked that the battalion unit's lawyer, Capt. Randy W. Stone, did not report the misconduct. The system “didn't work at Haditha," one interviewee noted, because the "judge advocate didn't encourage the commanding officer to investigate." 202 The marines ultimately court-martialed Captain Stone, as well as three other officers, including the commander, Lt. Col. Jeffrey R.

\footnotetext{
${ }^{196}$ Interview with JAG Officer No. 1, supra note 92.

${ }^{197}$ Interview with JAG Officer No. 3, supra note 140.

${ }^{198} \mathrm{Id}$.

${ }^{199}$ Interview with JAG Officer No. 5, supra note 115.

${ }^{200} \mathrm{Id}$.

${ }^{201}$ Paul von Zielbauer, Marines' Trials in Iraq Killings Are Withering, N.Y. TIMES, Aug. 30, 2007 , at A1.

${ }^{202}$ Interview with JAG Officer No. 5, supra note 115.
} 


\section{DRAFT-DO NOT CITE OR QUOTE \\ REFER TO FINAL PUBLISHED VERSION: 104 AM. J. INT'L L. 1 (2010).}

Chessani, of the Third Battalion, First Marines. ${ }^{203}$ Although the charges against the lawyer (as well as two of the other three officers) were ultimately thrown out, ${ }^{204}$ many of the judge advocates interviewed criticized him for going astray. One said that "the JAG got charged for a cover-up because he didn't tell—he went native." That is, "his loyalty to the command trumped his ethical duty, and because he was in combat with them, it was very difficult." ${ }^{205}$ But, this judge advocate concluded, "He needed to report the [problems]. That's what JAGs are needed for: you have to have an unquestionable level of integrity ... [and] it needs to trump the loyalty to the command."206 Another judge advocate pointed to one of the problems at Haditha as lack of "sunshine" because the lawyer failed to report the misconduct up the chain of command. ${ }^{207}$

Expanding outward from the Haditha case, many of the judge advocates underlined the importance of saying no in some cases, but figured that framing the legal advice in other ways was generally the better option. One judge advocate explained that "it's my ethical duty to say no, and not every officer sees that as necessary."208 Often, he observed, "you can get to yes, but sometimes [you] have to go through a circuitous route." For example, "There are ways of creatively saying no without saying no."209 According to the same judge advocate, "I never had to say no," because his "commander stayed "in the box . . . [and] didn't try to get creative.",210 In today's military, the authorities are disciplining soldiers who use excessive force.

Thus, a recent report on detainee abuse cases concluded that one-third of the uniformed military personnel implicated in abuse were recommended for court-martial or other disciplinary

\footnotetext{
${ }^{203}$ Interview with JAG Officer No. 2, supra note 108.

${ }^{204}$ Interview with JAG Officer No. 5, supra note 115.

${ }^{205} \mathrm{Id}$.

${ }^{206} I d$.

${ }^{207}$ Interview with JAG Officer No. 2, supra note 108.

${ }^{208} I d$.

${ }^{209} \mathrm{Id}$.

${ }^{210} I d$.
} 


\section{DRAFT-DO NOT CITE OR QUOTE \\ REFER TO FINAL PUBLISHED VERSION: 104 AM. J. INT'L L. 1 (2010).}

proceedings, and most of those received criminal or administrative penalties. ${ }^{211}$ While the report criticizes the military for not punishing more soldiers, and for failing to punish high-ranking officers, the percentage of those punished is much higher than it is for, say, military contractors. Indeed, of twenty contractors implicated in the cases documented in the report, only one faced criminal punishment. $^{212}$

Uniformed judge advocates are also playing a broader role within the executive branch. For example, they were a powerful force behind revising the Bush administration's detainee treatment rules to prohibit torture, and they strongly criticized the limited due process protections for terrorist suspects brought before military commissions. ${ }^{213}$ Indeed, numerous judge advocates have resigned rather than take part in proceedings before military commissions. For example, two air force prosecutors, Maj. John Carr (a captain at the time) and Maj. Robert Preston, requested that they be reassigned rather than participate in the proceedings, having charged that fellow prosecutors were ignoring torture allegations, failing to protect exculpatory evidence, and withholding information from superiors. ${ }^{214}$ More recently, Lt. Col. Darrel Vandeveld, a U.S. military prosecutor at Guantánamo, quit because his office suppressed evidence that could have cleared a client. $^{215}$ The interviews recounted here suggest that, at the very least, having an independent Judge Advocate General's Corps embedded with troops has some constraining effect by injecting public values into volatile wartime contexts.

${ }^{211}$ Human Rights FiRSt, By the Numbers: Findings OF THE DETAINEE ABUSE AND ACCOUNTABILITY PROJECT 7 (2006), available at http://www.humanrightsfirst.info/pdf/06425-etn-by-the-numbers.pdf.

212 Id. at 3.

${ }^{213}$ For a discussion of the ways a military culture steeped in rules of law proved resistant to Bush administration initiatives, see Laura A. Dickinson, Abu Ghraib, in INTERNATIONAL LAW STORIES (John E. Noyes, Laura A. Dickinson, \& Mark W. Janis eds., 2007).

${ }^{214}$ Jess Bravin, Two Prosecutors at Guantanamo Quit in Protest, Wall STREet J., Aug. 1, 2005 , at B1.

${ }^{215}$ Peter Finn, Guantanamo Prosecutor Quits, Says Evidence Was Withheld, WASH. Post, Sept. 25, 2008, at A6 (Met 2 ed.). 


\section{DRAFT-DO NOT CITE OR QUOTE \\ REFER TO FINAL PUBLISHED VERSION: 104 AM. J. INT'L L. 1 (2010).}

\section{CONCLUSION}

Even when all four of the organizational characteristics that tend to correlate with an effective compliance regime are in place, the mere existence of military lawyers does not guarantee that legal norms will be obeyed. Moreover, these lawyers are likely to overstate their own importance as agents of compliance. In any event, this is simply one case study.

Nevertheless, both the literature on organizational theory and the on-the-ground observations of military lawyers suggest that when we think about international law compliance, we cannot ignore organizational structure and institutional culture. Indeed, reforms aimed at structure and culture may well run deeper and last longer than other possible efforts to induce greater compliance. Consider, for example, reforms aimed at nonstate entities such as private security contractors. If we wish to render such entities more likely to abide by external legal norms, we may find that tackling internal organizational structure and institutional culture may be more effective than trying to impose additional rules. ${ }^{216}$ Accordingly, instead of focusing exclusively on new treaties or new international judicial rulings that seek to inculcate norms formally, we might instead look to how best to alter organizational structure and institutional culture on the ground. ${ }^{217}$

${ }^{216}$ See, e.g., Laura A. Dickinson, Public Values/Private Contract, in Government By CONTRACT: OUTSOURCING AND AMERICAN DEMOCRACY (Jody Freeman \& Martha Minow eds., 2009); Laura A. Dickinson, Contract as a Tool for Regulating Private Military Companies, in FROM MERCENARIES TO MARKET: THE RISE AND Regulation of Private Military Companies (Simon Chesterman \& Chia Lenhardt eds., 2007); Laura A. Dickinson, Public Law Values in a Privatized World, 31 YALE J. INT'L L. 383 (2006); Laura A. Dickinson, Government for Hire: Privatizing Foreign Affairs and the Problem of Accountability Under International Law, 47 WM. \& MARy L. Rev. 135 (2005); see also LAURA A. Dickinson, Outsourcing WAR AND PEACE (forthcoming 2009).

${ }^{217}$ The potential link between organizational structure and legal compliance, for example, suggests further developing Michael P. Scharf's study of the State Department legal advisers, see Scharf, supra note 8, to see whether aspects of the State Department's organizational structure or institutional culture play a role in how effective the legal adviser is. Indeed, one might compare the institutional context of the legal adviser's office at the 


\section{DRAFT-DO NOT CITE OR QUOTE \\ REFER TO FINAL PUBLISHED VERSION: 104 AM. J. INT’L L. 1 (2010).}

At any rate, we need to deepen our debates about compliance and study the variety of

institutional and organizational structures that can significantly affect law-abiding behavior on a day-to-day basis. Government bureaucracies, international organizations, transnational

corporations, trade associations, tribes, clans, and even terrorist networks are all, at root level, collections of individuals. The decision-making processes of these collectivities are significantly shaped by their organizational structures and institutional cultures. Consequently, if scholars can gather better contextual qualitative information about how such structural and cultural questions turn out in individual cases, we will assemble a far better understanding of the knotty issues of norm compliance that continue to bedevil international legal theorists.

State Department with that of legal advisers' offices in other agencies (or in other countries) to see whether aspects of organizational structure influence the efficacy of each office. 